\title{
SUPERCRITICAL FLUID EXTRACTION: RECENT ADVANCES AND APPLICATIONS
}

\author{
Miguel Herrero ${ }^{1,2}$, Jose A. Mendiola ${ }^{1}$, Alejandro Cifuentes ${ }^{1}$, Elena Ibáñez ${ }^{1}{ }^{*}$
}

${ }^{1}$ Instituto de Fermentaciones Industriales (CSIC), Juan de la Cierva 3, 28006 - Madrid, Spain ${ }^{2}$ Sección Departamental Ciencias de la Alimentación, Universidad Autónoma de Madrid, Campus de Cantoblanco, 28049 - Madrid, Spain.

\section{Contents:}

1. INTRODUCTION

2. SFE APPLIED TO FOOD AND NATURAL PRODUCTS EXTRACTION.

2.1. General aspects.

2.2. Food applications

2.3. By-products processing using SFE

2.4. Natural products applications

2.5. Applications to drugs extraction from natural sources: analysis and isolation

3. SFE IN PHARMACEUTICS

3.1. Applications to enantiomeric separations

3.2. Solvent removal and new drug delivery formulations

4. ENVIRONMENTAL APPLICATIONS OF SFE

4.1. SFE in food toxicology and ecotoxicology

4.2. Metals recovery using supercritical fluids

\section{CONCLUSIONS \\ 6. REFERENCES}

\section{* Corresponding author:}

Elena Ibáñez

Tel.: + 34915618806

Fax: +34915644853

elena@ifi.csic.es

Keywords: Supercritical Fluid Extraction; Foods; Natural products; By-products; Pharmaceutical; Heavy Metal; Environmental 


\begin{abstract}
:
Among the different extraction techniques used at analytical and preparative scale, Supercritical Fluid Extraction (SFE) is one of the most used. This review covers the most recent developments of SFE in different fields, such as food science, natural products, by-product recovery, pharmaceutical and environmental sciences, during the period 2007-2009. The revision is focused on the most recent advances and applications in the different areas; among them, it is remarkable the strong impact of SFE to extract high value compounds from food and natural products but also its increasing importance in areas such as heavy metals recovery, enantiomeric resolution or drug delivery systems.
\end{abstract}




\section{1.- INTRODUCTION}

Solvent extraction is one of the oldest methods of separation known and certainly dates back to Palaeolithic age. The science of solvent extraction has evolved over a long period of time and much progress has been made in the understanding of solvation and the properties of liquid mixtures used in extraction processes. Hannay and Hogarth's (1879) early observations of the dissolution of solutes in supercritical fluid (SCF) media introduced the possibility of a new solvent medium. However, it is only quite recently (around 1960) that commercial process applications of supercritical fluid extraction have been extensively examined [1].

The massive wide scale use of organic solvents by a diverse range of global industries represents a serious threat to the environment. In part response, the Montreal Protocol was introduced in 1987 with an initial objective to restrict or eliminate the manufacture and use of particularly damaging ozone depleting solvents such as chlorofluorocarbons (CFCs). The Montreal Protocol is dynamic and evolving with the manufacture and supply of solvents other than CFCs gradually being restricted. Years of negotiation fostered by the United Nations Environment Programme has now resulted in more than 170 signatory nations to the Montreal Protocol with its London (1990), Copenhagen (1992) and Beijing (1999) amendments. Consequently, world-wide there is pressure for industry to adopt new sustainable processes that do not require the use of environmentally damaging organic solvents [2].

Since the end of the 1970s, supercritical fluids have been used to isolate natural products, but for a long time applications relayed only on few products. Now the development of processes and equipment is beginning to pay off and industries are getting more and more interested in supercritical techniques [3]. This interest is also reflected in the high amount of scientific papers dealing with Supercritical Fluid Extraction (SFE) published in recent years. Moreover, industrial applications of SFE have experienced a strong development since the early 1990's in terms of patents [4]. 
In 2007 we published a review paper dealing with the use of compressed fluids (SCFs among them) for sample preparation [5]; since then, several applications have appeared in the literature. Therefore the main purpose of the present review paper is to cover the recent advances and developments of SFE mainly in Food, Toxicological, Pharmaceutical and Environmental fields during the period 2007-09, including all the papers dealing not only with the use of SFE as sample preparation technique but also with the analytical scale SFE process development.

As will be seen throughout this paper, the main supercritical solvent used is carbon dioxide. Carbon dioxide (critical conditions $=30.9^{\circ} \mathrm{C}$ and 73.8 bar) is cheap, environmental friendly and generally recognized as safe by FDA and EFSA. Supercritical $\mathrm{CO}_{2}\left(\mathrm{SC}_{-}-\mathrm{CO}_{2}\right)$ is also attractive because of its high diffusivity combined with its easily tunable solvent strength. Another advantage is that $\mathrm{CO}_{2}$ is gaseous at room temperature and pressure, which makes analyte recovery very simple and provides solvent-free analytes. Also, important for food and natural products sample preparation, is the ability of SFE using $\mathrm{CO}_{2}$ to be operated at low temperatures using a non-oxidant medium, which allows the extraction of thermally labile or easily oxidized compounds [5]. The main drawback of $\mathrm{SC}-\mathrm{CO}_{2}$ is its low polarity, problem that can be overcome employing polar modifiers (co-solvents) to change the polarity of the supercritical fluid and to increase its solvating power towards the analyte of interest. For example, the addition of relatively small percentages (1-10\%) of methanol to carbon dioxide expands its extraction range to include more polar analytes. The modifiers can also reduce the analyte-matrix interactions improving their quantitative extraction [6]. Due to the high amount of literature dealing with the basics of SFE, the reader is referred to some interesting books and papers [1-9].

The design of processes using supercritical solvents is strongly dependent on the phase equilibrium scenario, which is highly sensitive to changes in operating conditions. Therefore, phase equilibrium engineering plays a key role in the synthesis and design of these processes. Phase equilibrium engineering is the systematic application of phase equilibrium knowledge to process development 
[10]. This knowledge comprises data banks, experimental data, phenomenological phase behavior, thermodynamic analysis, and mathematical modeling procedures for phase equilibrium process calculations. Each SC application has a set of specifications and physical restrictions. Rigorous simulations of equilibrium stage separations at near-critical conditions are needed for the design and optimization of supercritical processes. However, equilibrium calculations in the near-critical region can present serious convergence difficulties. In that respect, Michelsen's phase stability criterion, multiple-phase flash algorithms, and global phase computations are of particular interest for supercritical extraction applications. The bases of phases equilibrium are out of the scope of the present review, but reader can be referred to the works performed by E. Brignole's group [11-16] among others.

\section{2.- SFE APPLIED TO FOOD AND NATURAL PRODUCTS EXTRACTION.}

\subsection{General aspects.}

From a simple literature search, it can be easily deduced the impact of SFE as sample preparation technique for the analysis of target compounds from natural products and foods. In this section, the most remarkable applications included in this group are commented and summarized. It is worth to mention that SFE has been also widely used in this field for process development, that is, to extract target (bioactive or valuable) compounds from different matrices. Even though these processes usually offer clear advantages over traditional ones, the main drawback for industrial scale use is the lack of realistic economical studies. In this sense, some papers have been lately published dealing with the assessment of the industrial economical feasibility of some developed processes, such as essential oil extraction from rosemary, fennel and anise [17] and brewer's spent grain management [18]. Therefore, SFE can be regarded as a possible tool not only from a laboratory point of view but also for the natural products and food industries. 
One of the main aspects that should be considered in SFE is the extraction optimization. The use of the optimum values for the different variables influencing the SFE extractions could significantly enhance the recovery or extraction yield of a target compound. With the aim to, effectively, optimize these variables (mainly extraction temperature, pressure, time, type and percentage of modifiers, sample size, etc.), different approaches have been applied. Those strategies can be grouped in phase equilibrium strategies and experimental design statistical optimization. Phase equilibrium engineering is the systematic application of phase equilibrium knowledge to process development. This knowledge comprises data banks, experimental data, phenomenological phase behavior, thermodynamic analysis, and mathematical modeling procedures for phase equilibrium process calculations [10]. The phase equilibrium and mass transfer are not modelling problems; they are limit stages of the process that can justify the results. It is very important to organize the experiments based in these fundamentals, to contribute to the understanding of the extraction problem.

Despite of the valuable information obtained by phase equilibrium engineering, it's a common practice to optimize the processes using experimental designs and statistical modelling. As reviewer said the information obtained with these methods is very specific and not easily applicable to other matrices, but it represents a very easy practical way for the optimization and scale up. The use of experimental designs is one of the most common strategies when it comes to set up robust extraction methods [19]. For instance, a simplex centroid design was used to determine optimum temperature, pressure, dynamic extraction time and modifier volume that maximize the yield of the essential oil of valerian (Valeriana officinalis L) attained by SFE using supercritical carbon dioxide [20]. Based on the graphical and statistical analysis of results, temperature and pressure were to be the influential variables on the extraction process, the optimum was found at $37^{\circ} \mathrm{C}$ and $243-250$ bar. With this strategy four independent variables were tested at five levels by using only 18 experiments. Response surface methodology (RSM) is another popular possibility; RSM was 
recently been applied to optimize the process parameters for supercritical carbon dioxide extraction of passion fruit oil [21]. The use of RSM allowed the simultaneous graphical optimization of the extraction temperature, pressure and extraction time. The extraction yield was selected as response variable, although the particular fatty acid composition of the extracts was subsequently studied by GC-FID [21]. RSM provide more information about how the extraction is working, but requires more experimental points. In the case of the extraction of passion fuit oil [21], fourteen experiments plus six replicates in the centerpoint were used to test 3 variables at 5 levels. This methodology has been also employed to optimize the extraction of other matrixes such as Pueraria lobata to obtain flavonoids [22] as well as wheat germ [23], pomegranate [24] and brazilian cherry extraction [25]. Besides, RSM using a full factorial composite design involving 3 factors (temperature, pressure and extraction time) and 3 levels, was employed to fit a second order polynomial model for the maximization of lycopene SFE extraction from tomato pomace [26,27]. A full statistical analysis of the results allowed the determination of $57{ }^{\circ} \mathrm{C}, 530$ bar and $1.8 \mathrm{~h}$ as optimum extraction temperature, pressure and time, respectively. Five levels were instead employed, together with the same factors, to the optimization of antioxidants extraction from roasted wheat germ. Yield, total phenolic and tocopherol contents and extracts antioxidant activity were used as response variables [27]. Full factorial designs require more experimental points, but provides more information in terms of the effect of variable combinations.

Orthogonal array designs can be effectively used to study the influence of 4 different factors simultaneously. This type of experimental design was employed to study the type of modifier, the dynamic extraction time, temperature and pressure of the supercritical $\mathrm{CO}_{2}$ in terms of extraction yield produced and $d l$-tetrahydropalmitine extracted from Corydalis yanhusuo, an herbal medicine [28]. Three levels of each variable were considered, and their optimal values determined through an ANOVA analysis. These designs can be used to estimate main effects using only a few 
experimental runs. These designs are also available to investigate main effects for certain mixed level experiments where the factors included do not have the same number of levels.

Thermodynamic simulations and theoretical models are also an alternative to process optimization [29,30]. For instance, a GC-EoS (Group Contribution Equation of State) model was applied to simulate the counter-current supercritical extraction of phytosterol esters [31]. Some extraction parameters have been studied particularly in detail, such as the effect of pressure on plant seeds extraction [32], the influence of milled seeds particle size distribution in the extraction process [33], or even deeper calculations of solubility changes in supercritical $\mathrm{CO}_{2}$ according to the temperature and pressure applied [34]. In fact, it was shown how the particle size significantly influenced the yield of paprika extract. Likewise, sample moisture above $18 \%$ negatively affected the extraction [35]. Moreover, different mass transfer models have been also employed to modeling vegetable oils extraction [36].

In food and natural products analysis, the performance of SFE compared to other advanced and /or conventional extraction techniques has been frequently evaluated. SFE has been directly compared to classical solvent extraction [37,38], soxhlet extraction [39], hydrodistillation [40-43], solid-liquid extraction [44], as well as ultrasound assisted extraction [37]. Besides the very well known advantages over other extraction techniques, such as the low consumption of organic solvents and selectivity [42], SFE has demonstrated to provide faster extractions and higher yields than hydrodistillation for the extraction of the essential oil of Valeriana officinalis [40]. In contrast, hydrodistillation provided better results in terms of number of volatiles extracted, although the loss of these compounds in the depressurization step after SFE was a possibility to consider. SFE was selected over solid-liquid extraction for the enrichment of phenolic compounds from grape pomace [44]. SFE produced higher phenolic concentrations than the traditional extraction technique, although the composition of the extracts was not exactly the same; while solid-liquid extraction contained more proanthocyanidins, SFE was richer on simple phenolics. Besides, the extracts 
obtained using this technique showed higher antiradical activity [44]. Moreover, SFE has demonstrated to be more effective than other conventional techniques for the extraction of antimicrobial compounds $[38,39]$.

A clear trend in food and natural products analysis, as well as in other fields of analytical science, is the hyphenation of sample treatment procedures with analytical tools in order to produce effective on-line couplings. Some of these couplings have involved the use of SFE. For instance, SFE has been directly coupled to a CE instrument with fluorimetric detection to effectively carry out the clean-up of the sample and the direct CE analysis of riboflavin from chiken liver and powdered milk [45]. A scheme of the instrumentation employed can be seen in Figure 1. As it can be observed, a continuous flow device allowed the coupling between the SFE and CE instruments. In a first step, the sample clean-up was performed using supercritical $\mathrm{CO}_{2}$; then, by actuating several switching valves, a carrier solution composed of methanol/water (95:5) was let to pass across the sample extracting the available vitamins and filling an injection loop. Later on, the valve was again actuated releasing the extract to the capillary inlet. There, a certain amount was injected in the CE system and analyzed [45]. Nevertheless, this is not the only direct coupling developed in the last years. Tithonia diversifolia was extracted using $\mathrm{CO}_{2}$ with the aim to obtain tagitinin $\mathrm{C}$ (a sesquiterpene lactone, with anti-plasmodial activity), which was directly determined by Fourier transform-Infrared spectroscopy (FT-IR) [46]. A high pressure fibre optic flow cell was installed in order to allow the real-time determination of the tagitinin $\mathrm{C}$ being extracted. This novel set-up allowed the monitoring of the SFE process as well as the determination of the kinetic curve of this compound [46]. Once its usefulness was demonstrated, the developed instrument was successfully employed to optimize the extraction of this compound from $T$. diversifolia, studying by real-time monitoring, the effect of varying the extraction pressure and temperature [47]. 
Thanks to the production of a clean extract when using supercritical $\mathrm{CO}_{2}$ as extraction solvent in SFE, the on-line coupling of this extraction technique with analytical tools, specially GC, is relatively straight-forward using different devices interfacing extraction and analysis [48,49]. Nevertheless, no application in the food and natural products field has been referenced in the last three years including this type of on-line coupling.

SFE has been also used in combination with other sample treatment processes; for example, polyphenols from cocoa seeds were effectively extracted and separated by combining SFE together with nanofiltration processes [50]. In this case, the extraction conditions were previously determined and then, the performance of different commercial nanofiltration membranes was studied. These membranes were placed in a special filtration cell before the collector. Besides, the permeability of the membranes to the supercritical $\mathrm{CO}_{2}$ was also studied [50].

\subsection{Food applications}

Probably, the most extended use of SFE is in the food field. A high variety of samples, type of materials, target compounds and procedures have been published in the last years.

A relatively new group of applications that have been recently developed includes the extraction and fractionation of carbohydrates by SFE. This technique, using supercritical $\mathrm{CO}_{2}$, as it is massively employed, is not at first sight the best option for this group of compounds, given the low polarity of carbon dioxide; however, using $\mathrm{CO}_{2}$ with a relatively low amount of polar entrainer, authors demonstrated its usefulness. A full factorial design was used to evaluate the influence of extraction pressure, temperature and modifier flow rate (and consequently proportion of modifier) to effectively fractionate carbohydrate mixtures formed by lactose and lactulose. Results obtained were analyzed by multiple linear regression determining as optimum values $100 \mathrm{bar}, 100{ }^{\circ} \mathrm{C}$ and 0.2 $\mathrm{ml} / \mathrm{min}$ of co-solvent (4\% modifier) for the selective recovery of lactulose [51]. This strategy was also applied to other carbohydrates [52,53]. All these works demonstrated the great importance of the modifier nature to obtain selective fractionations, being ethanol/water the most successfully 
used co-solvent. In fact, the solubilities of different carbohydrates in supercritical carbon dioxide with ethanol/water as co-solvent were experimentally obtained and thermodynamically modelled [54]. The optimization of mannitol extraction from olive leaves has been also performed, although the extraction yield in terms of mannitol extracted was lower than that attained using Soxhlet [55].

Crude vegetable oils are widely used in the food industry for a number of applications. Usually oils have to be refined to remove undesirable compounds before consumption; during this refining process, valuable compounds contained in the oils can be also lost. SFE has been suggested as an alternative to refining procedures, to obtain extracts enriched with the particular compounds of interest; this is the case for instance of wheat germ oil [56], green coffee oil obtained by pressing [57], rice bran oil [58] or crude palm oil [59].

SFE has been also used to remove unwanted compounds from other matrices; for example, supercritical $\mathrm{CO}_{2}$ with water as co-solvent has been employed to selectively extract caffeine from green tea while avoiding the extraction of antioxidants from the matrix [60]. The selectivity of the different extraction conditions studied was confirmed by HPLC.

Essential oils [61-65], fatty acids $[61,62,65]$ and/or bioactive compounds $[62,64,66,67]$ have been extracted from fruits and vegetables using supercritical $\mathrm{CO}_{2}$. Soy isoflavones have been also widely studied; aqueous methanol seems to be the most appropriate modifier to carry out isoflavones supercritical $\mathrm{CO}_{2}$ extractions [68], although the use of acetonitrile has been also tested [69]. Daidzein and genistein were successfully extracted at high pressures, from 350 to 500 bar $[68,70]$. In all of these studies, HPLC was the analytical tool selected to determine these flavonoids. These compounds as well as other bioactives have been extracted by SFE prior analysis from a number of matrices: stilbenes such as cajaninstilbene from pigeonpie [71], cinnamic derivatives from propolis [72] or carotenoids and flavonoids from black rice [73]. 
SFE has demonstrated to be a useful tool to investigate fatty acids profile in fish oils [59]. Fractionation of fish oils with supercritical $\mathrm{CO}_{2}$ to obtain omega-3 enriched fractions was possible by operating at different temperatures and pressures $[74,75]$. These authors found that the tuning of the extraction parameters made supercritical extraction a helpful procedure to effectively change the lipids composition, so that a high value functional product is obtained. One of the few works dealing with SFE using a solvent different from $\mathrm{CO}_{2}$ is related to fatty acid extraction from a fish oil sample [76]. In this case, the ability of ethane as an alternative to the more common use of $\mathrm{CO}_{2}$ to extract fatty acids was evaluated. Besides, a thermodynamic modeling was used to obtain the most appropriate conditions to extract the highest possible amounts of eicosapentanoic (EPA) and docohexaenoic (DHA) acids. Ethane provided better selectivity and higher solubility for EPA and DHA esters as compared to other esters containing the same number of carbons. Applying $60{ }^{\circ} \mathrm{C}$ and 84 bar, a concentration of $60 \%$ of both fatty acids ethyl esters could be obtained using ethane as supercritical solvent [76].

Phospholipids are widely employed in the food industry, not only for their technological properties but also for their biological functions. Two SFE processes (without and with ethanol as modifier) together with a supercritical antisolvent procedure in a semi-continuous process have been suggested as an effective way to produce a very pure phospholipid extract from egg yolk powder at industrial scale [77]. SFE was also useful to concentrate more that 5-fold the phospholipids present in whey cream buttermilk powders [78]. These phospholipids were later on separated on a HPLC diol column and detected using an evaporative light-scattering detector (ELSD). This kind of products have been also investigated for their fatty acids content, extracted by SFE [79].

Supercritical $\mathrm{CO}_{2}$ is the most widely used near-critical fluid for the extraction of lipids. However, $\mathrm{CO}_{2}$ cannot extract complex lipids unless an organic co-solvent is also used. Among the other near- 
and super-critical fluids that could be considered, we have found that dimethyl ether (DME) is a strong solvent for both neutral and polar lipids and has a wide range of potential use in food, pharmaceutical, and cosmetic applications. DME is non-toxic, non-reactive, does not cause a $\mathrm{pH}$ change in aqueous solution, and has a sufficiently high vapour pressure at room temperature that virtually complete solvent removal can be carried out easily and at moderate, or ambient, temperatures. Catchpole et al [80] combined the use of $\mathrm{CO}_{2}$ and DME for the extraction of phospholipids from egg yolk and a special dairy stream. A two step extraction process is described in which neutral lipids are extracted with supercritical $\mathrm{CO}_{2}$, and then polar lipids using near-critical DME. The polar lipid extract was enriched in phospholipids ( $\sim 70 \%$ by mass), which included phosphatidylcholine, phosphatidylethanolamine, phosphatidylinositol, phosphatidylserine, and sphingomyelin. Other complex lipid components extracted included gangliosides and cerebrosides. Unlike the antisolvent process, proteins were not denatured during either $\mathrm{CO}_{2}$ or DME processing of the spray dried powders, and the de-fatted powders are therefore suitable for a range of functional foods. A polar lipid extract could also be produced from spray dried powder by extracting first with DME to obtain a mixed neutral/complex lipid extract, then re-extracting the lipid extract with $\mathrm{CO}_{2}$ to remove neutral lipids.

One strategy to increase the extraction efficiency of food materials is an enzyme pre-treatment [81]. It has been repeatedly shown that some enzyme treatments on the sample just prior extraction can effectively help to the extraction of the target compounds. This strategy was employed with soybean oil deodorizer distillate to increase the recovery of phytosterols esters present on this byproduct [82]. After a two-step enzymatic treatment, phytosterol esters were concentrated in the raffinate up to $82 \%$ with a yield reaching $72 \%$, using $\mathrm{CO}_{2}$ at 250 bar and $55{ }^{\circ} \mathrm{C}$ and a solvent-tofeed ratio of 35 [82].

As it can be appreciated, these treatments are mainly focused to increase the extraction yield. To this aim, besides enzymes, other pretreatments can be performed. Recently, Zhang et al. [83], 
compared the SFE extraction performance (yield and chemical composition of extracts) of almonds with and without autoclaving pretreatment. Authors found that the fatty acid profile suffered just minor modifications whereas the extraction yield was significantly increased due to the rupture of the almond cell walls during the treatment in the autoclave [83].

SFE has been also widely employed as a sample treatment technique prior to volatiles analysis in different beverages. Aroma compounds from sugar cane spirits were isolated by supercritical $\mathrm{CO}_{2}$ [84]. The application of mild pressures and temperatures (100 bar and $40^{\circ} \mathrm{C}$, respectively) allowed the highest concentration of aroma compounds that were subsequently analyzed by GC-MS and using sensory evaluation. Recently, an application was proposed for the removal of ethanol from alcoholic beverages using supercritical carbon dioxide [85]. Vacuum distillation, membrane techniques and $\mathrm{CO}_{2}$ supercritical fluid extraction $(\mathrm{CO} 2-\mathrm{SFE})$ can be used in the dealcoholization process. All these techniques have the disadvantage of eliminating the beverage aromas together with ethanol, but still, among them, $\mathrm{SC}-\mathrm{CO}_{2}$ is particularly attractive because water, salts, proteins and carbohydrates are not substantially removed or denatured. The removal of ethanol from alcoholic beverages implies a problem of ethanol separation from aqueous solutions, since most alcoholic beverages contain large amounts of water. In this paper [85] a different approach was followed. The GC-EoS thermodynamic model was used to correlate the $\mathrm{CO}_{2}+$ ethanol+water phase behavior and to simulate a countercurrent multistage separation process. As expected, extraction $(\mathrm{T}$, P) with the same $\mathrm{CO}_{2}$ density produced almost the same elimination of ethanol; at a given $\mathrm{CO}_{2}$ density the ethanol content in the dealcoholized product can be controlled by tuning the solvent to beverage flow ratio.

One of the most interesting recent applications of SFE in food analysis sample treatment dealt with the determination of amino acids profiles in different genetically modified varieties of maize and 
soybean [86]. Supercritical $\mathrm{CO}_{2}$ modified with $35 \%$ methanol at $80{ }^{\circ} \mathrm{C}$ and 120 bar was employed to extract the amino acids, that were afterwards analyzed by GC-MS. These optimal extraction conditions were provided by a central composite design and the statistical analysis of the obtained data. The sum of the areas of the aromatic amino acids was selected as the experimental design response variable. This way, several genetically modified organisms (GMO) could be directly compared to their respective isogenic non-trasgenic varieties. Some statistical differences among the amino acids contents in the samples studied were observed [86]. The extraction with modified $\mathrm{CO}_{2}$ allowed a faster and more efficient recovery of amino acids from maize and soybean grains compared with previous techniques.

\section{3.- By-products processing using SFE}

Industrial activities generate a large variety of by-products and wastes ranging from manure to packing residuals. Strong research is focused in the development of new technologies and new uses for these materials in order to reduce their environmental impact. New processes are being developed to recover components producing high added value products [87]. Mainly SFE has been tested for the extraction of lipids and lipophilic components, but not only, as can be seen in Table 1. SFE has been widely used to value food industry by-products; these products are generated during food manufacturing and normally do not have any commercial value. By-products extraction allows the removal of valuable/interesting compounds that otherwise cannot be utilized. Rice wine lees were investigated for the extraction of polyphenols with antioxidant activity [88]. The amount of modifier (ethanol) used, combined with supercritical carbon dioxide, was shown to be the most critical factor to maximize polyphenols extraction. In this paper Soxhlet ethanol extraction was compared with $\mathrm{SC}-\mathrm{CO}_{2}+$ ethanol, polyphenols content was only $43 \%$ of that obtained by Soxhlet ethanol extraction, on contrast, SFE needs much shorter extraction times. 
The tomato-related industry produces a number of by-products, such as peels or pomace, in which the presence of carotenoids has been confirmed. These compounds act as pigments and have been described to possess several interesting functional activities, for instance antioxidant activity [109], ability to prevent cardiovascular diseases [110], macular degeneration [111] and cancer prevention [112]. These activities obviously make carotenoids very interesting for the food industry. Tomato pomace, containing skin and seeds of ripen tomatoes has been extracted using SFE in order to obtain not only carotenoids [113,114] but also tocopherols and phytosterols [89]. Later on, the extracts were analyzed by HPLC and GC in order to determine their contents on the interesting compounds. It was observed that the use of $\mathrm{CO}_{2}$ at 460 bar and $80{ }^{\circ} \mathrm{C}$ produced extract with the highest carotenoid content, being more than $90 \%$ lycopene. On the other hand, extracts rich in tocopherols and phytosterols were obtained at 300 bar and $40{ }^{\circ} \mathrm{C}$ [89]. In a subsequent work, a central composite rotatable design model was used to optimize the SFE conditions to extract lycopene from tomato skin waste [90]. The complete statistical analysis of the data generated predicted $62{ }^{\circ} \mathrm{C}$ and 450 bar as optimum extraction conditions, using $\mathrm{CO}_{2}$ with $14 \%$ ethanol concentration. Under these conditions the recovery of all-trans lycopene was 33\%. In other to obtain lycopene from tomato, recently, a novel procedure has been proposed. Ciurlia et al. [91], studied the simultaneous extraction of tomato and hazelnuts in order to extract lycopene from tomatoes and essential hazelnut oil at a time. The application of $\mathrm{CO}_{2}$ at $60{ }^{\circ} \mathrm{C}$ and 400 bar resulted on the extraction of the $72.5 \%$ of the lycopene present on the tomatoes, and $80 \%$ of the hazelnut oil. The product was an over-saturated solution of lycopene in hazelnut oil. Besides, after centrifugation, a product five-folds more concentrated on lycopene was attained. HPLC-UV using a specially suited column for carotenoids analysis (C30 stationary phase) was employed to characterize the extracts and products obtained. Authors concluded that this novel approach was an effective way to increase the lycopene extraction from tomato powder [91]. 
Carotenoids and tocopherols recovery from Sea buckthorn pomace (a by-product of Sea buckthorn juice manufacture process) [92] and from fresh palm-pressed mesocarp fiber (by-product from palm oil production) [93] have been also studied. As could have been seen most of the papers dealing with carotenoids extraction requires very high pressures, this fact suppose a di By-products of vegetable oil production are one of the most studied matrices $[115,116]$. Other matrices that have been also evaluated were hake by-products, to obtain omega-3 rich extracts [94], sugar cane crude wax, coming from sugar cane production, to obtain long chain $n$-alcohols [95], pomegranate seeds from juice production to obtain polyphenols [96], loquat seeds, in the search of phytosterols [97] and tea stalk and other tea plant wastes to extract caffeine [98].

Many recent works deals with oil recovery from different residues, namely, wood [105], corn [101] or even silkworm pupae [107]. Desilked silkworm pupae is the main by-product of the silk industry, and it constitutes $60 \%$ of dry cocoon weight; only China generates more than 700.000 tons of silkworm pupae per year; from this, only a small amount is as fertilizer and animal feed. Wey et al. [107] optimized, by response surface methodology, a method to obtain a high value oil from desilked silkworm pupae with $\mathrm{SC}-\mathrm{CO}_{2}$. In this case, the use of SFE contribute keep unaltered the composition of the oil, while other techniques for oil recovery can modify the fatty acid profile. Through an experimental design, considering four variables (pressure, temperature, extraction time and $\mathrm{CO}_{2}$ flow), authors concluded that oil yield was linearly dependent on pressure and extraction time while the quadratic terms of pressure, extraction time, and $\mathrm{CO}_{2}$ flow rate and the interactions between pressure and temperature and temperature and flow rate were also significant. A polynomial regression model was used to describe the experimental results, the optimal condition for silkworm pupal oil yield was found to be 324.5 bar, $39.6{ }^{\circ} \mathrm{C}, 131.2 \mathrm{~min}$, and $19.3 \mathrm{~L} / \mathrm{h}$. Furthermore, unsaturated fatty acids were the predominant fatty acids in the silkworm pupal oil, as the GC-MS analysis concluded. 
Biocrude is a replacement for geologically sourced crude oil, made from biomass. Biocrude is a next-generation non-fossil form of energy which can be transported and refined using existing petroleum facilities, this is why biocrude is different from biodiesel. The primary biofuel in use today is corn- or cane-based ethanol, which exhibits several negative characteristics; these include the very large amount of energy required to create ethanol from corn, and the corrosive effect of ethanol on piping and engine components. The rising price of grain leads to increase in the final cost of grain-based ethanol. The use of supercritical fluids in bio-fuel production has been recently reviewed by Wen et al. [117]. Woodwaste and forestry residues could be a promising source of biocrude whose possibilities have been studied by Yang \& Gilbert [105]. In this work, the use of supercritical methanol was suggested since it seems to enhance the dissolution rate of lignocellulosic materials, to increase the linkage rate of $\alpha$ and $\beta$-ether linkages while keeping intact the condensed linkages. The birch wood sawdust was treated, without catalyst, in methanol at 20$100 \mathrm{bar}, 200-400^{\circ} \mathrm{C}$. Once the reactor was cooled to room temperature, the gas inside was collected in a gas cylinder, and was analyzed by GC-TCD, while the residual products were analyzed by GCMS. Besides, several catalysts $\left(\mathrm{NaOH}, \mathrm{K}_{2} \mathrm{CO}_{3}\right.$, or $\left.\mathrm{Rb}_{2} \mathrm{CO}_{3}\right)$ were assayed in order to tune the biocrude composition. In the optimized conditions $\left(20 \mathrm{bar}, 200{ }^{\circ} \mathrm{C}\right.$ and $\left.2 \mathrm{~h}\right)$ the obtained heavy oil products consisted of a high concentration of phenol derivatives, esters, and benzene derivatives, and also contained a higher concentration of carbon, a much lower concentration of oxygen, and a significantly increased heating value $(>30 \mathrm{MJ} / \mathrm{kg}$ ) when compared with the raw woody biomass. Hydro-liquefaction in supercritical methanol can thus be a promising technique for upgrading of woodwastes of a low-heating value to bio-crude with a significantly increased heating value.

\subsection{Natural products applications.}


SFE has for long been used to extract bioactive compounds from plant materials in order to characterize compounds responsible for an specific functional activity. In Table 2, a summary of the recent works published on this topic is shown. As it can be seen, antioxidant compounds have been the most frequently studied. It is interesting to note that in every application $\mathrm{CO}_{2}$ with or without organic modifiers was the solvent employed. Concerning the analytical techniques used to characterize the extracts, GC and HPLC were utilized. High speed counter-current chromatography was also employed to characterize isocoumarins and other compounds from coriander [72] and Cynanchum paniculatum [118], respectively.

As it can be inferred from Table 2, most of these works were aimed on the characterization of bioactives from medicinal herbs, or on the extraction of these compounds to be used as ingredients intentionally added to other products, mainly food products [119-137]. The extraction of carotenoids from different samples has been studied. While 450 bar and $80^{\circ} \mathrm{C}$ were used to extract this compounds from rosehip [32], milder conditions were applied to test Eugenia uniflora as a source of these compounds. However, in both cases $\mathrm{CO}_{2}$ without the addition of any modifier and HPLC-UV were employed to obtain, characterize and quantify these compounds at $450 \mathrm{~nm}$ [138]. Other interesting compounds studied included coumarins [121,133], tocopherols, fatty acids [122], phytosterols [126] and terpenes [131,135], among others. Blood-thinning, anti-fungicidal and antitumor activities have been associated to coumarins [121]. An artificial neural network model was employed to determine the optimum extraction conditions; using supercritical $\mathrm{CO}_{2}$ with a $2 \%$ of methanol as co-solvent at $55^{\circ} \mathrm{C}$ and 250 bar for $150 \mathrm{~min}$, a coumarin yield of $90.1 \mu \mathrm{g} / \mathrm{g}$ was obtained from Cuscuta reflexa, a medicinal herb [121]. Another example is the extraction and analysis of $\beta$-sitosterol and stigmasterol [126]. These compounds are classified as phytosterols and they are regarded as possessing several bioactivities including the reduction of cholesterol levels, anti-inflammatory, anti-mutagenicity and prevention of cancer. The SFE extracts of A. roxburghii were analyzed by HPLC-APCI-MS in order to determine the amount of these compounds. The SFE 
optimized conditions produced higher yields in shorter times than traditional Soxhlet methods, reaching $2.9 \%$ and $3.6 \%$ for b-sitosterol and stigmasterol, respectively [126].

In general, as it can be observed in Table 1, a wide variety of samples and compounds of interest have been studied. The optimum extraction conditions obviously varied between samples, as did the most influential parameters; among them, sample pretreatment prior extraction, entrainer addition, particle size and temperature and pressure have been studied in detail. For instance, the entrainer was the key parameter when extracting xanthones from Garcinia mangostana concerning the extraction yield [139]. On the other hand, the extraction pressure was the most important in other samples, such as Hibiscus cannabinus [75] while high pressures were used to extract bioactive compounds from sunflower leaves [140]. Particle size was also demonstrated to influence in great extent the outcome of the extraction procedure [136]. As for sample pretreatment, no significant differences were observed when processing dried samples compared to frozen ones [140]. In summary, a careful optimization procedure was needed for each particular sample, paying special attention to the specific target compounds. Moreover, one of the fundamental advantages of SFE over other extraction techniques was repeatedly demonstrated, that is, the tuneable selectivity according to the extraction conditions, mainly extraction pressure and temperature [138,142].

A quite similar overview can be inferred from the works dealing with algae and microalgae. These organisms have been highlighted in the search for feasible new sources of natural antioxidants and functional compounds that could be employed in the food industry [157]. Both types of organisms include a huge variety of species, increasing the interest of finding, among them, new sources of bioactives. Moreover, in the case of microalgae, the production of a particular interesting compound can be further improved by changing the growing conditions at which these organisms are cultured. It is well known that the production in these organisms of certain secondary metabolites is directly related to this growing conditions, such as temperature, salinity, light or nutrients available [158]. In 
Table 3, a summary of the published works in the last years concerning the use of algae and microalgae to obtain bioactive compounds by SFE is shown.

Dunaliella salina is one of the most studied microalgae; for long, this organism has been cultured at industrial scale to produce $\beta$-carotene. In fact, the amount of $\beta$-carotene this microalgae can accumulate can reach $14 \%$ of its dry weight [171]. As it has been already mentioned, carotenoids are very appreciated for their antioxidant properties, among others. Macías-Sánchez et al. [161], recently studied the SFE of carotenoids from several microalgae, including D. salina. Several pressures and temperatures were tested in order to maximize carotenoid extraction using supercritical $\mathrm{CO}_{2}$ with $5 \%$ ethanol as co-solvent. The total carotenoids in the different extracts was assessed spectrophotometrically. Authors found that optimum conditions varied among the different studied microalgae, being 400 bar and $60^{\circ} \mathrm{C}$ the best conditions for carotenoid extraction from Dunaliella. This organism was, besides, the one which produced higher amount of these components [161]. In a subsequent work, the same research group compared the efficiency of SFE compared to ultrasound assisted extraction (UAE) to extract these carotenoids, as well as chlorophylls, from D. salina [160]. They concluded that although both techniques were comparable in terms of carotenoids extracted (using methanol and $\mathrm{CO}_{2}$ for UAE and SFE, respectively), SFE was by far more selective since it produced higher values of the ratio carotenoid/chlorophyll extracted. The kinetics of the carotenoids SFE extraction have been also studied in detail [172]. The $\beta$-carotene isomer composition as well as the antioxidant activity of $D$. salina SFE extracts were determined [159]. HPLC-DAD using a C30 column was employed in order to effectively resolve the different $\beta$-carotene isomers present on the extracts. Moreover, a certain relationship was found between the isomeric b-carotenoid composition and the antioxidant activity of the extracts, especially according to the concentration of 9-cis- $\beta$-carotene present. 13-cis, all-trans, 15-cis and 9cis- $\beta$-carotene were separated and quantified together with $\alpha$-carotene [159]. 
Other microalgae were investigated in order to determine their composition on particular carotenoids. For instance, $87 \%$ of total lutein in Chlorella pyrenoidosa was achieved at optimized SFE conditions, which included the extraction at 250 bar and $50{ }^{\circ} \mathrm{C}$ using supercritical $\mathrm{CO}_{2}$ with $50 \%$ ethanol as modifier [165]. This carotenoid is interesting not only for it antioxidant activity but also for being useful for prevention of age-related macular degeneration. Authors found that the selectivity of SFE allowed the attainment of high purity products, therefore suggesting that the process could be used for lutein commercial production [165]. Another interesting work studied the possibility of obtaining a functional food oil rich in antioxidants from Chlorella vulgaris [166]. Different parameters were studied in detail, and it was concluded that the degree of crushing of the microalgae mixed with soybean oil strongly influenced the extraction recovery. The resulting enriched soybean oil presented a double effect: firstly, the pigments present contributed to oil stability due to their antioxidant effect, and in the other hand, the oil worked as a protector of the carotenoids degradation.

Carotenoids have not been the only target compounds. In fact, the extraction of $\gamma$-linolenic acid from Spirulina platensis by SFE has been also studied [169,170], as well as the tocopherols content in the same microalgae $[167,168]$. Likewise, GC-MS was employed in order to characterize the volatiles extracted by SFE fom the brown alga Dictyopteris membranacea [163].

\section{5.- Applications of SFE to drugs extraction from natural sources: analysis and isolation}

SFE results in a high valuable tool when it comes to find novel pharmaceutical activities of extracts from natural matrices. In this field, plants and marine living beings are the main subjects of research. For example, mistletoe (Viscum album L.) has been studied for its possible cytotoxic effect on Ehrlich carcinoma cells [151]. Most pharmacological studies on mistletoe have focused on the therapeutic properties of its polar extracts; but Ćebović et al. [151] treated the mistletoe leaves with $\mathrm{CO}_{2}$ at 350 bar and $34-35^{\circ} \mathrm{C}$ to obtain new extracts, whose composition was analyzed using a 
common GC-MS method with a HP5 column and a temperature gradient from 50 to $350^{\circ} \mathrm{C}$. Several new terpene compounds were identified by this method including trans- $\alpha$-bergamotene, trans- $\beta$ farnesene, loliolide and vomifoliol. The extracts were injected in mice before and after carcinoma induction. The largest decrease was observed in mice pretreated with the Viscum album extract, although significantly reduced numbers of Ehrlich carcinoma cells were also observed in animals with developed carcinoma. The activities of antioxidative enzymes in the Ehrlich carcinoma cells suggested the absence of oxidative stress. However, changes in the antioxidative enzymes activities observed after administration of the Viscum album extract might be due to the induction of oxidative stress in the Ehrlich carcinoma cells.

Some other pharmacological activities related to the antioxidant activity of supercritical extracts have been studied. For example, antioxidant therapy has been proposed to improve the oxidative stress status of diabetic patients. Rupérez et al. [173] performed the metabolic fingerprinting and target metabolite analysis of Dunaliella salina microalga extracts on diabetic rats. As seen above, D. salina carotenoids have been previously characterized and associated to its antioxidant activity by using SFE [159]. In this case, Rupérez et al. used extracts with proved antioxidant and antimicrobial activities obtained by using PLE $[174,175]$ and SFE $[159,176]$. Urine fingerprints of control and diabetic rats, both with and without treatment, were obtained by capillary electrophoresis with two different modes (normal polarity and MEKC and reverse polarity and CZE). CE was also used for target metabolite analysis, in this case glutathione as well as four short chain organic acids (acetoacetate, 3-hydroxybutyrate, lactate, and pyruvate) and urate. Chemometric data treatment was done using multivariate data analysis (principal components analysis (PCA) and partial least squares discriminant analysis (PLS-DA) to achieve more in-depth knowledge of the results.

SF extracts have also been tested on Lehismaniosis; Soares et al. [152] studied the leishmanicidal activity of a supercritical fluid fraction obtained from Tabernaemontana catharinensis (jasmine). 
The extract was obtained at 250 bar, $45^{\circ} \mathrm{C}$ using supercritical $\mathrm{CO}_{2}$ plus ethanol $(4.6 \% \mathrm{~m} / \mathrm{m})$ as cosolvent, alkaloidal fraction of the extract was analyzed with TLC, GC-MS, and other spectrometric methods such as IR, UV and $\mathrm{H}^{1}$-NMR, concluding that besides coronaridine and voacangine (two previously characterized indolic alkaloids [177]), the alkaloidal fraction contain voacangine hydroxylindolenine, voacristine, voacristine hydroxylindolenine, and 3-hydroxylcoronaridine. Authors conclude that SFE is an efficient method for the extraction of bioactive indole alkaloids from plant extracts, while retaining the alkaloids' properties associated with inhibiting Lehismania amazonensis amastigote replication in macrophages without incurring host cell toxicity.

Nowadays the search of new antiviral compounds is more and more important in order to fight new types of virus. SFE has also been applied to the search of those new antiviral extracts from natural sources. For example, Šmidling et al. [153] described the examined cytotoxicity and extracellular and intracellular antiviral activity of fractionated extracts of wild and cultivated sage (Salvia officinalis) against vesicular stomatitis virus (VSV). In this work, dried sage ethanolic tinctures were treated with $\mathrm{SC}-\mathrm{CO}_{2}$ at $200-500$ bar and $60-100{ }^{\circ} \mathrm{C}$ during long extraction times, $6 \mathrm{~h}$. The main compounds found in extracts by HPLC and GC were terpenoids and phenolic terpenes. The fraction obtained with $\mathrm{CO}_{2}$ at 500 bar and $100^{\circ} \mathrm{C}$ was the least toxic for human amnion epithelial cells; moreover, it had an antiviral effect at the intracellular level: when added 5 hours before VSV infection, it caused 100\% reduction of CPE (cytopathic effect) at concentrations of 99.5 and 199.0 $\mu \mathrm{g} / \mathrm{ml}$. The obtained results indicate that antiviral activity of this extract involved inhibition of the early steps of the virus infective cycle without a direct virucidal effect.

Hippophae rhamnoides L. (Sea buckthorn) is a branched and thorny nitrogen-fixing deciduous shrub, widely spread along Europe and Asia. It has been described that Sea buckthorn has significant antioxidative activity related to its content in carotenoids and tocopherols [92], but Basu, Upadhyay et al. examined new uses of Sea buckthorn: anti-atherogenic and cardioprotective activities [155] and wound healing properties [154]. Sea buckthorn seed oil extraction was carried 
out at $60{ }^{\circ} \mathrm{C}$ and at 450 bar with a gas flow of $60 \mathrm{~g} / \mathrm{min}$ for $3 \mathrm{~h}$. GC-FID was used to analyze the fatty acid profile of supercritical extracted seed oil, while different HPLC-DAD methods were used to analyze the content in tocopherols and sterols. In the first work [155] it was observed that the HDL-cholesterol levels, HDL-C/Total cholesterol ratio and vasorelaxant activity of the aorta were significantly increased. In cholesterol-fed animals the Total cholesterol, Triglycerides, LDLcholesterol and Atherogenic index were significantly increased and showed a decline following seed oil administration. The presence of Omega-3 and Omega- 6 fatty acids, tocopherols, phytosterols and $\beta$-carotene were pointed as responsible of cardioprotective effects of SBT seed oil to which in combination may have synergistic effects on cardiovascular health. In the second work [154] Hippophae rhamnoides seed oil was co-administered by two routes on experimental burn wounds in rats. The Hippophae rhamnoides seed oil improved the wound healing process as evidenced by a significant increase in wound contraction, hydroxyproline, hexosamine, DNA and total protein contents in comparison to control. Gelatin zymography analysis of the granulation tissue after seed oil treatment showed increased expression of metalloproteinases, while SDSPAGE and Western blot analysis showed an up-regulated expression of VEGF and collagen type-III in SBT seed oil treated wounds as compared to untreated control burn wounds.

\section{3.- SFE IN PHARMACEUTICS}

Proprietary pharmaceutical product development is driven by continuous innovations in drug discovery, drug polymorph preparation, dosage form design, and process engineering, while meeting rigorous regulatory standards. Innovations in all these areas are feasible with the application of technologies utilizing supercritical fluids (SCFs) [178]. Pharmaceutical companies are more and more urged to develop production processes with very low environmental impact, in particular to reduce the use of volatile organic compounds in medicine manufacturing as well as to 
avoid residues in the finished product. Other benefits of supercritical fluid technologies, apart from their mass transfer related properties, are linked to the reduced complexity of the process which stems from a diminution of the number of steps as well as to the improved process understanding and control $[2,179]$.

The main uses of supercritical fluids in pharmaceutical industry include processes such as particle and crystal engineering [180], formation of complexes with cyclodextrins (CDs), coating, foaming and tissue engineering, enzymatic reactions in supercritical media, extrusion, production of liposomes and biotechnological compounds [181], purification of pharmaceutical excipients [182], sterilization, solvent removal [179], enantioselective separations [183] and, of course, extraction and purification of active principles from raw materials and from synthetic reaction media.

In general terms, the main use of supercritical fluids in pharmaceutics deals with the extraction of bioactive compounds from a mixture (purification from reactions, quantification of active enantiomer, extraction from natural matrices...) or with the extraction of the matrix. In this case, crystallization and particle formation have undergone an enormous development in recent years.

\section{1.- Application of SFE to enantiomeric separations}

Chiral separation is a very important issue for the pharmaceutical industry. The applicability of SFE as an effective and green technique for enantioseparations is known since the late 90 s $[8,184-187]$. In these processes, diastereomeric salts or complexes of the racemic compounds and resolving agents are formed before the extraction step. The selected resolving agent is added in less than stoichiometric ratio to the racemic compound. The unreacted enantiomers are extracted with the supercritical solvent, and are collected as a powder after depressurization of the solution [188]. For example Molnár et al. [188] reported a new and simple resolution for the enantiomers of trans-1,2cyclohexanediol by diastereomeric complex formation with tartaric acid and subsequent 
supercritical fluid extraction, and showed the influence of the extraction parameters on the resolution efficiency. Tartaric acid and its derivatives are widely used and are considered low cost chiral agents in resolutions through diastereomeric complex or salt formation [189]. Racemic trans1,2-cyclohexanediol and (2R,3R)-(+)-tartaric acid were dissolved in ethanol; the reaction product was extracted under different conditions $\left(P=100-200 \mathrm{bar}, T=33-63^{\circ} \mathrm{C}\right)$ with $\mathrm{CO}_{2} / \mathrm{g} \mathrm{rac}$ using a laboratory scale supercritical unit. The $(1 S, 2 S)-(+)$ rich mixture was collected in the separator at 40 bar and $40{ }^{\circ} \mathrm{C}$. The enantiomeric excesses were determined by GC-FID analysis with a chiral column with permethylated $\beta$-cyclodextrin. Optimal conditions in terms of resolution efficiency, according to a $3^{2}$ factorial design, were found within the studied range of the extraction pressure and temperature. In the best cases, the $(1 S, 2 S)$ - and $(1 R, 2 R)$-diol enantiomers were obtained with $\mathrm{ee}_{(1 S, 2 S)}=62 \%$ and $\mathrm{ee}_{(1 R, 2 R)}=93 \%$ enantiomeric excess in one equilibrium stage, respectively.

Other example of the use of SFE for the resolution of racemic mixtures by using tartaric acid was developed by Kmecz et al. [189]. In this work, tartaric acid is used in combination with derivatives (O,O'-dibenzoyl-(2R,3R)-tartaric acid monohydrate (DBTA) and O,O'-di-p-toluoyl-(2R,3R)tartaric acid (DPTTA)), for the separation of racemic N-methylamphetamine (rac-MA). After partial diastereomeric salt formation, the free enantiomers were extracted by SFE using $\mathrm{CO}_{2}$ as solvent at 160 bar and $39^{\circ} \mathrm{C}$ (flow rate: $0.9-1.1 \mathrm{~g} / \mathrm{s}$ ). Enantiomeric excess $\left(e_{\mathrm{X}}\right.$ ) values of the samples were determined by optical rotatory measurement. DBTA and DPTTA are efficient resolving agents for rac-MA, the best chiral separation being obtained at a molar ratio of 0.25 resolving agent to racemic compound for both resolving agents $\left(\mathrm{ee}_{\mathrm{E}}=82.5 \%\right.$ and $\mathrm{ee}_{\mathrm{E}}=57.9 \%$, respectively). Compared with the two other acids, TA is practically unsuitable for enantiomer separation $\left(e_{\mathrm{E}}<5 \%\right)$. As could have been seen, $\mathrm{SFE}$ represents a faster and easier alternative to conventional techniques for the racemic resolution. On contrast, its generally needed the use of compounds that helps the separation which may produce contaminations in the final product. 
Supercritical fluid chromatography (SFC) also shows enormous advantages for chiral separations [190-195]: packed-column supercritical fluid, subcritical fluid, and enhanced fluidity liquid chromatography have gained popularity in the analytical determination of drug substances and food compounds. The advantage of SFC on chiral separation lies in the low viscosity and high diffusivity of the mobile phase with $\mathrm{CO}_{2}$; very high flow rates of $5-10 \mathrm{ml} / \mathrm{min}$ can be used to decrease elution times while maintaining the separation efficiency [191]. SFC method development can be done in a comprehensive way, as seen in the work developed by Gham et al. [194]. Three major considerations for a successful scale-up in SFC are the impurity profile, the cycle time, and the solubility in the supercritical mobile phase. These authors use these three factors in order to assist the scale-up of the entantiomeric separation of a proprietary pharmaceutical intermediate. In this work, chiral packed columns were used for the analytical and preparative scale in combination with a UV fixed wavelength detector. But SFC can be applied for chiral separation coupled to other detectors, such as MS/MS [195]. Coe et al. [195] used SFC-MS/MS for fast bioanalysis of R/Swarfarin in human plasma, and developed a pSFC-MS/MS (preparative-SFC-MS/MS) method twofold faster than previously described. But probably the main development in the supercritical fluid field for the enantiomeric separation is the Simulated Moving Bed (SMB) technology, which can be defined as a continuous multi-column chromatographic process. This technology has been thoroughly reviewed recently by Rajendran et al. [190].

\section{2.- Solvent removal and new drug delivery formulations}

In order to enhance the bioavailability of poorly water-soluble drugs, an increasing number of pharmaceutical formulation technologies are being developed; these include micronization, complex formation and solid dispersions [196]. In the case of polar compounds which are not soluble in supercritical fluids (particularly $\mathrm{CO}_{2}$ ), SCFs could be used as antisolvent; in this process, a solution consisting of an organic solvent, completely miscible with the SCF, and a solid material 
dissolved in this solvent, is sprayed into a high-pressure vessel filled with SCF [197]. In these processes the supercritical fluid is used to extract the solvent instead of the analyte. In recent years, several reviews $[7,179,180,198,199]$ and original researches [200-212] have dealt with particle formation processes. Some examples

Crystallization is one of the most widely purification techniques used after a chemical synthesis. The purification and fractional crystallization using a gas anti-solvent (GAS) type SCF process exploits the sharp change in solvation power that occurs as a solvent expands. Unlike conventional crystallization processes, supersaturation in gas anti-solvent crystallization processes depends on pressure; therefore, solutes with differing solubility will precipitate at different stages of expansion. A typical scheme of a supercritical crystalization apparatus can be seen in Figure 2. Thus, SCF- $\mathrm{CO}_{2}$ processing allows the isolation of certain process impurities from active pharmaceutical ingredients (APIs) which may include reaction intermediates, enantiomers and additives. Nucleation occurs at the point where the solute concentration exceeds the solubility in the solution [7]. Generally, the success of supercritical antisolvent precipitation process depends on the solubility of the liquid solvent in the supercritical antisolvent and based on the fact that the solute is not soluble in the antisolvent. It also depends on the fast solubilization of the liquid due to the gas-like diffusion characteristic of SCF; this characteristic is fundamental to obtain small particles.

Argemí et al. [212] described in very thorough way the spectroscopic and chromatographic characterization of triflusal (2-acetoxy-4-(trifluoromethyl) benzoic acid) delivery systems prepared by using supercritical impregnation technologies. Triflusal is an antithrombogenic drug structurally related to acetylsalicylic acid. Characterization assays comprised the determination of the percentage of triflusal and its degradation product impregnated in polymeric supports and further monitoring of the releases of the two drug components over time in physiological conditions. The analytical methods employed consisted in a continuous-flow spectroscopic system to measure the 
evolution of the drug concentration in the solution as a function of time, and an HPLC-UV method to determine the percentage of impregnation and to monitor the drug release. Also, the chromatographic approach provided additional information regarding the presence of triflusal hydrolysis product and its evolution over long periods of time. From the set of samples prepared at different experimental conditions, the best behavior from a pharmaceutical point of view corresponded to the case of poly(methyl methacrylate) beads impregnated according to the supercritical procedure for $48 \mathrm{~h}$ at $190 \mathrm{bar}$ and $40{ }^{\circ} \mathrm{C}$. In these samples, the amount of triflusal impregnated corresponded to an $11.4 \%$ and a constant release in aqueous media was expected to be longer than 2 months.

Wu et al. [200] studied the formation of solid dispersions of a poorly water-soluble drug piroxicam (a non-steroidal anti-inflammatory drug) in polyvinylpyrrolidone (PVP) comparing a supercritical fluid crystallization process and classical spray drying. Physicochemical properties of the products and drug-polymer interactions were characterized by powder X-ray diffraction, Fourier transform infrared spectroscopy, differential scanning calorimetry and HPLC-UV-Vis. Both processes resulted in improved dissolution of piroxicam; by comparison, supercritical processed solid dispersions showed distinctly superior performance dissolving piroxicam completely. Solutions were injected into the precipitation chamber through the inner capillary and meanwhile steady flow of $\mathrm{CO}_{2}$ was introduced through the outer nozzle. After injection, compressed $\mathrm{CO}_{2}$ flushed through the precipitation chamber to extract the residual organic solvent from the product. Authors demonstrated that supercritical processing is more powerful in controlling particle size. The physical transformation nature of this technique seems not to interfere with the interactions between drug and carrier, making possible the use of this method to control the in vitro performance without compromising the stability issue.

Salmaso et al. [201] prepared homogeneous dispersions of insulin and recombinant human growth hormone (rh-GH) in tristearin/phosphatidylcholine/PEG mixtures supercritical carbon dioxide gas 
micro-atomisation to produce protein-loaded lipid particles. In this work [201], a home-made equipment "supercritical gas-assisted melting atomization process" [202] was used, this apparatus was pressurized with $\mathrm{CO}_{2}$ at 150 bar and heated to $40{ }^{\circ} \mathrm{C}$; several analytical techniques were applied to the homogeneous dispersions obtained, namely: differential scanning calorimetry analysis (DSC), transmission electron microscopy (TEM) and UV-Vis spectrophotometry. The insulin and rh-GH content in the lipid particles was assessed by DMSO extraction and HPLC analysis. With this procedure insulin could be administrated orally producing a significant hypoglycaemic effect comparable with the classical injected drug, leading relative pharmacological bioavailability of $7 \%$. The importance of finding alternative ways for the administration of insulin was also studied by Kim et al. [203], who examined the effect of stabilizers on the physicochemical characteristics of the aerosol of inhaled insulin particles produced using a supercritical fluid technology. Growth hormone prepared using supercritical fluids [201] and administrated orally produced a relative pharmacological bioavailability of $3.4 \%$.

Chu et al. [204] prepared fine particles of cefpodoxime proxetil (CPD) using a slightly different particle formation process called Aerosol Solvent Extraction System (ASES) with supercritical $\mathrm{CO}_{2}$. CPD is an oral third generation cephalosporin, active against most Gram positive and Gram negative organisms. In this work, the degree of agglomeration was reduced using a high $\mathrm{CO}_{2}$-tosolution weight ratio, and a low solution concentration. In particular, spherical particles, approximately $0.1-0.4 \mu \mathrm{m}$ in size, were obtained when a $10.0 \mathrm{wt} \% \mathrm{CPD}$ solution was used. As a result of the dissolution study, almost $90 \%$ of the processed CPD had dissolved within 10 min. The recovery yield of the CPD powder reached approximately $80 \%$ using a membrane filter.

Vatanara, Rouholamini et al. have studied the use of supercritical crystallization of several antiasthma drugs such as salbutamol sulphate [205] or fluticasone [206] using solution enhanced dispersion by $\mathrm{SC}-\mathrm{CO}_{2}$. The use of supercritical fluid extraction of the matrix, coupled to a controlled crystallization facilitates the inhalatory administration of those drugs. In these studies the 
morphology and size distribution of precipitated particles were characterized using scanning electron microscope (SEM) and laser diffraction particle size analyzer respectively. FTIR spectra was used before and after processing to asses crystal modifications, and the amount of active principles determined using the HPLC methods of the European Pharmacopoeia.

Among the various approaches that have been used to improve the solubility and dissolution rate of drugs, complexation with cyclodextrins is one of the most promising. Cyclodextrins are cyclic oligomers of glucose with cone-like structures, whose exterior surface has hydrophilic properties, while the interior is hydrophobic in nature. This particular characteristic of cyclodextrins allows them to form non-covalent inclusion complexes with various drugs of proper size and polarity leading to changes in their physicochemical and biopharmaceutical properties, which enhance their solubility, dissolution rate, chemical stability and bioavailability and reduce their side effects and toxicity [213]. The use of $\mathrm{SC} \mathrm{CO}_{2}$ has been recently proposed for the preparation of various drugcyclodextrin inclusion complexes for enhanced solubility and dissolution rate. The $\mathrm{SC} \mathrm{CO}_{2}$ inclusion method of cyclodextrins of several antifungal drugs such as itraconazol [214], econazole and fluconazole [215] have been studied. In both works higher inclusion yields were obtained in the $\mathrm{SC} \mathrm{CO}_{2}$ method as compared to physical mixing and co-precipitation methods. In vivo drug pharmacokinetic studies showed that the drug- $\beta$-cyclodextrin product prepared using $\mathrm{SC} \mathrm{CO}_{2}$ display higher bioavailability (in blood, liver and kidney of rats) as compared to the products obtained by conventional procedures. In the $\mathrm{SC} \mathrm{CO}_{2}$ inclusion method, the reaction cell was filled with a physical mixture of drug and $\beta-\mathrm{CD}$. The system was then pressurized and heated up to the desired pressure and temperature. After keeping the system in a static mode for $3 \mathrm{~h}$, at 450 bar and at temperatures ranging $50-130{ }^{\circ} \mathrm{C}, \mathrm{CO}_{2}$ with solvent residue was extracted from the cell. The solubility of fluconazole in $\mathrm{SC}-\mathrm{CO}_{2}$ was significantly larger than that of itraconazole and econazole. The higher solubility of fluconazole and the possibility of fluconazole to be melted at the $\mathrm{SC} \mathrm{CO}_{2}$ conditions lead to higher extent of interaction between the drug and $\beta-\mathrm{CD}$ as compared to 
itraconazole and econazole, which was verified by DSC, FTIR and PXRD analysis. In vivo drug pharmacokinetic studies showed that ingestion of drug complexed with $\beta$-cyclodextrin using the solvent-free $\mathrm{SC} \mathrm{CO}_{2}$ results in a higher bioavailability of the drug as compared to the products obtained by physical mixing or co-precipitation method, indicating the superiority of the $\mathrm{SC} \mathrm{CO}_{2}$ method. Moreover, antifungal- $\beta$-cyclodextrin complexes prepared using $\mathrm{SC} \mathrm{CO}_{2}$ made the drug available to liver and kidney tissues for at least $6 \mathrm{~h}$ after ingestion, therefore, the dose could be lowered.

But not only cyclodextrins have been under research to form more soluble drugs complexes; a novel group of lipid based drug delivery systems, called pharmacosomes, is also growing [216]; their uses have been recently reviewed by Semalty et al. [216]. Pharmacosomes provide better biopharmaceutical properties to the drug, resulting in improved bioavailability. Li et al. [217] compared the physicochemical characteristics of the phospholipids complex of puerarin (an isoflavone used to treat fever, pain, diabetes, measles, diarrhea, and cardiovascular diseases including coronary artery disease, arrhythmia and hypertension) prepared by traditional methods (solvent evaporation, freeze-drying and micronization) and a supercritical fluid (SCF) technology. The phospholipid-puerarin complexes were prepared as follows: the reaction vessel was filled with puerarin and phospholipids solutions and $\mathrm{CO}_{2}$ was added at 100 bar and $38^{\circ} \mathrm{C}$, and left for $3 \mathrm{~h}$. A pure constant carbon dioxide flow rate of $25 \mathrm{ml} / \mathrm{min}$ was then maintained in order to completely remove the residual solvent. Drug-phospholipids interactions were characterized using FTIR. SEM was used to determine any morphological changes. Pharmaceutical performance was assessed in dissolution rate and solubility tests using UV spectroscopy. The complexes prepared by using the described protocol exhibited more rapid dissolution and showed some advantages in terms of particle size and morphology. 


\section{4.- ENVIRONMENTAL APPLICATIONS OF SFE}

There is no doubt that the industrial activity of mankind has generated too much carbon dioxide giving rise to an imbalance in the biosphere; perhaps ironically, the use of SCF carbon dioxide can significantly help to reduce further $\mathrm{CO}_{2}$ emissions if the need to transport and incinerate waste organic solvents from manufacturing processes is decreased [2]. In fact, several recently developed applications of supercritical fluids not only tend to eliminate organic solvents, but also to reduce the environmental impact of human activities. In this sense, applications like removal of heavy metals from soils, sludges and wastes, reduction of secondary wastes generation, regeneration of inactive catalysts or methods for treating soils contaminated with non polar compounds (PAH, PCB...) are being studied [218,219].

\section{1.- SFE in food Toxicology and Ecotoxicology}

There are several compounds with serious health implications which determination can be done using SFE, the main areas of application include food toxicology and ecotoxicology. In addition, SFE has been adopted by the EPA as a reference method for extracting Petroleum Hydrocarbons (Method 3560, in 1996) PAHs (Method 3561, in 1996) and PCBs (Method 3562, in 2007) from solid environmental matrices. SFE has been recently used for extracting POPs from different plant materials [220], and several analytical applications dealing with POPs extraction from different animal tissues have also been reported [5].

As seen in Table 4, SFE is used to measure contaminants in sediments. It is important to quantify the impact of human activities in the environment, and soils and sediments are good markers of this impact. For example, Miyawaki et al. [221] developed a very fast strategy to quantify polychlorinated dibenzo- $p$-dioxins (PCDDs), polychlorinated dibenzofurans (PCDFs), 
polychlorinated biphenyls (DL-PCBs) and dioxins in soils and sediments. Farming and industrial soils samples were extracted using $\mathrm{SC}-\mathrm{CO}_{2}$ with water as modifier, at $300 \mathrm{bar}, 130{ }^{\circ} \mathrm{C}$ and $50 \mathrm{~min}$; contaminants were trapped using a SPE cartridge filled with alumina (maintained at $150^{\circ} \mathrm{C}$ ) and eluted with hexane; their concentration was quantified by GC-MS. In order to evaluate the usefulness of this protocol, authors compared to the results obtained using the classical clean-up procedure followed by Soxhlet extraction. The average concentration of PCDD/DFs and DL-PCBs were comparable between techniques, and the reproducibility of the SFE method was below $21 \%$ of the relative standard deviations for all samples. Some advantages of the new protocol were the total analysis time, only $2 \mathrm{~h}$, and the possibility of analyzing the extracts eluted from the solid phase trap without a further clean-up procedure. On contrast the classical procedure needs near 3 days for the total analysis.

In a similar way as seen for dioxins and $\mathrm{PCB}$, other residues of human activities can be extracted and quantified by SFE. Mmualefe [232] evaluated the impact of agriculture in the Okavango river delta, by assessing the levels of 15 pesticides. In this work, three different extraction conditions were compared: pure $\mathrm{CO}_{2}$ (one step: 400 bar, $60{ }^{\circ} \mathrm{C}$ ), $\mathrm{CO}_{2}+\mathrm{H}_{2} \mathrm{O}$ (two steps: $60{ }^{\circ} \mathrm{C}, 200$ bar and 60 ${ }^{\circ} \mathrm{C}, 400$ bar) and $\mathrm{CO}_{2}+$ acetone (three steps: $60{ }^{\circ} \mathrm{C}, 200$ bar; $60{ }^{\circ} \mathrm{C}, 350$ bar and $60{ }^{\circ} \mathrm{C}, 400$ bar). GCTOF was used to identify the pesticides extracted, while GC-ECD was used for quantification purposes with external standard calibration. $\mathrm{CO}_{2}+$ acetone as modifier and fractional extraction by pressure ramping gave the highest recoveries ranging from 55 to $86 \%$ for the 15 pesticides studied. The study showed an increase of pesticide concentration in the direction of the water flow from the Panhandle (point of entry) to the lower delta; these results demonstrated a clear need for a close monitoring of our natural resources for long-term preservation purposes. 
Along with soils and sediments, algae and microalgae are the best indicators of contamination of water environments. SFE was used by Lage-Yusty et al. [235] to measure the residual levels of PAHs in edible seaweed, five years after an oil spill. Dehydrated seaweeds were treated at $100{ }^{\circ} \mathrm{C}$ and 256 bar during $50 \mathrm{~min}$ in continuous-flow mode at a rate of $1.5 \mathrm{~mL} / \mathrm{min}$ of supercritical $\mathrm{CO}_{2}$. In order to maximize the recovery of PAHs, a C18 trap was used to collect the extracts. After extraction, PAHs were eluted using acetonitrile and analyzed by HLPC-FLD. The levels found were below maximum limits established by the Spanish Food Safety authority $(<200 \mathrm{mg} / \mathrm{kg}$ dry weight); meaning that no relevant effects were detected in terms of PAHs contamination in seaweed.

But not only inorganic or vegetable material can be used to measure contamination. Fish, for instance, is also a good indicator of environmental contamination, mainly in its fat fraction [223,237]. A single-step extraction and clean-up procedure was used by Rodil et al. [223] for the determination of 15 organohalogenated pollutants in aquaculture products (turbot, clam, mussel and cockle). The extraction procedure was screened by a fractional factorial design for the preliminary statistically significant parameters. To reduce the number of experiments, a fractional factorial $2^{5-1}$ design, leading to 16 experiments, was used. The extraction temperature $\left(60-120^{\circ} \mathrm{C}\right)$, pressure (140-320 bar), static extraction time (5-20 $\mathrm{min})$, dynamic extraction time (10-60 min) and carbon dioxide flow rate $\left(1-2.5 \mathrm{ml} \mathrm{min}^{-1}\right)$ were studied. A Doehlert design, followed by a multicriteria decision-making strategy, was then performed in order to determine the optimum conditions for pressure and dynamic extraction time. As previously, a C18 trap was used to maximize the recovery of organohalogenated compounds. Under optimal conditions, the procedure developed along with GC-ECD and GC-MS/MS provides an excellent linearity, detection (0.01-0.2 ng. $\left.\mathrm{g}^{-1}\right)$ and quantification limits $\left(0.05-0.8 \mathrm{ng} \cdot \mathrm{g}^{-1}\right)$ for most of the analytes investigated.

The last example of SFE application to toxicology consists on the measurement of veterinary drug residues developed by Abd El-Aty et al. [236]. The method consisted on the quantification of 
orbifloxacin (third-generation fluoroquinolone antibacterial drug used in ruminant farming) in plasma and milk. Samples were adsorbed in filter paper and then extracted using SFE with $\mathrm{SC}-\mathrm{CO}_{2}$ containing methanol as modifier. The extraction conditions studied were 250-320 bar and 60-150 ${ }^{\circ} \mathrm{C}$. The extracts were collected in methanol previous to the HPLC-FLD analysis. The analytical method was developed and validated in this work, and was applied to a pharmacokinetic study for evaluating the main pharmacokinetic parameters of orbifloxacin in plasma and milk of seven lactating does; the method showed an appropriate sensitivity, demonstrating the usefulness of SFE for future application in pharmacokinetic and clinical studies, both in human and animal medicine.

\section{2.- Metals recovery using supercritical fluids}

Removal of heavy metals from solid matrices and liquids remain a big challenge and, although various methods have been described for this purpose, SFE seems to be one of the most promising [219]. Complexing agents used in conventional solvent extraction can also be used in SFE complexation of metal ions, provided that they are soluble in supercritical $\mathrm{CO}_{2}$. Solubilities of metal complexes in supercritical $\mathrm{CO}_{2}$ vary significantly depending on the chemical nature of the complexes. Numerous chelating or complexing agents have been employed in the SFE of heavy metals, such as diisooctyl-thiophospinic acid (Cyanex 302), sodium diethylthiocarbamate (Aliquat 336), bis(2-ethylhexyl)phosphoric acid) and bis(2-ethylhexyl)monothiophosphoric acid [219]. In fact, most of recent works deal with the optimization of the chelating agent to extract metals from different matrices, Table 5 .

Wang \& Chiu [239] developed a green method to remove chromated copper arsenate (CCA) from wood before its dumping, incineration, reuse or disposal, using supercritical carbon dioxide $\left(\mathrm{ScCO}_{2}\right)$ containing an organophosphorus reagent, Cyanex 302. Chromated copper arsenate has been used extensively as a wood preservative since 1940. After shelf life, treated wood caused 
environmental hazard, therefore, metal removal is highly important. In this work, the extraction efficiency was improved by adding a chelating agent to the wood sample. The extraction was performed at 200 bar and $60^{\circ}$, using $\mathrm{CO}_{2}+5 \%$ methanol as extracting solvent and considering 20 min static extraction followed by $40 \mathrm{~min}$ dynamic extraction. The eluent released from SFE system was trapped in a $30 \mathrm{ml}$ vial with $10 \mathrm{ml}$ of methanol inside. Extraction residues were analyzed by neutron activation analysis (NAA) and ICP-AES. The extraction efficiencies for the extraction of CCA were in the order of $\mathrm{Cu} \gg \mathrm{As}>\mathrm{Cr}$. The extraction profiles descend rapidly, followed by a plateau of metal extractions, suggesting that the process is limited to the leachable toxic heavy metals. By increasing pressure and static extraction time, the process efficiency can increase to $95 \%(\mathrm{Cu}), 66 \%(\mathrm{As})$ and $50 \%(\mathrm{Cr})$, respectively, after eight successive batchwise extractions. The in situ chelation/SFE showed advantages over conventional solvent extraction, in which it greatly minimizes the generation of secondary wastes in decontamination processes and helps alleviate the land filling and potential chromated copper arsenate contamination problems.

Organophosporus chelating agents are highly useful when it comes to extract metals by using SFE; they have even demonstrated its usefulness by extracting radioactive metals such as thorium [240]. Kumar et al. investigated the feasibility of supercritical $\mathrm{CO}_{2}$ extraction of thorium from tissue paper using various organophosphorus reagents (TBP, TOPO, TPP, TPPO, TBPO). Optimum extraction conditions were: $200 \mathrm{bar}, 60{ }^{\circ} \mathrm{C}, 2 \mathrm{~mL} \mathrm{~min}{ }^{-1}$ (CO2 flow rate), $20 \mathrm{~min}$ static time and $20 \mathrm{~min}$ dynamic extraction time. The maximum extraction efficiency was obtained with $0.2 \mathrm{M}$ TOPO in methanol where thorium was extractable with $68 \pm 4 \%$ efficiency. Thorium is not the only radioactive metal that have been extracted using SFE, Gavrilescu et al. have reviewed recently the possibilities of SFE in the remediation of soils contaminated with uranium [246]. In fact, the surface decontamination of radioactive metal wastes using acid-in-supercritical $\mathrm{CO}_{2}$ emulsions have been proposed by Koh et al. [241] as suitable candidate to decontaminate radioactive metal wastes using 
an environmentally friendly process. Microemulsions were prepared at a molar ratio $(W=20)$ between the surfactant (NP-4) and water into the cell at $40{ }^{\circ} \mathrm{C}$ and 200 bar. After $1 \mathrm{~h}$, microemulsions were transferred to a separator by depressurization, water droplets in unstable microemulsions started to agglomerate to each other and were finally separated from the surfactant. Then, with the pressure and temperature being maintained, the surfactant, still dissolved in $\mathrm{CO}_{2}$, was separated from the water droplets and collected through dynamic flushing of $\mathrm{CO}_{2}$. Finally, the collected surfactants were analyzed by HPLC. Organic acid-in- $\mathrm{CO}_{2}$ microemulsions achieved over 95\% efficiency, while using inorganic acid decontamination efficiencies were about $90 \%$. In this process, $73 \%$ of the total surfactants was recovered and could be reused, which means that secondary waste can be minimized considerably. Therefore, the supercritical fluid surface decontamination may be an effective candidate for surface decontamination of radioactive metals in the near future.

Other applications of supercritical fluids in the environmental field deal with their use as oxidizing agents. Supercritical water oxidation has been widely studied [247-250]; these processes always use very high temperatures $\left(>400{ }^{\circ} \mathrm{C}\right)$ and mild pressures $(200-300$ bar). At these conditions, water becomes a strong oxidizer, therefore, by using adequate chelating agents, the heavy metal extraction can be controlled. In fact, some authors even used $\mathrm{H}_{2} \mathrm{O}_{2}$ to favour the oxidation of metals, for example Bo et al. [248] investigated the application of $\mathrm{H}_{2} \mathrm{O}$ and $\mathrm{H}_{2} \mathrm{O}_{2}$ to the elimination of heavy metals in medical waste incinerator fly ash. By using $320-420$ bar and $450{ }^{\circ} \mathrm{C}$ during $1-4 \mathrm{~h}$, heavy metals in exchangeable and carbonate forms in the ashes could be transferred into other relatively stable forms ( $\mathrm{Ba}$ and $\mathrm{Cr}$ into residual fraction; $\mathrm{Cu}$ and $\mathrm{Pb}$ into organic matter fraction). $\mathrm{H}_{2} \mathrm{O}_{2}$ treatment could stabilize heavy metals in Fe-Mn oxides and residual fractions; however, the behaviour of As was quite different from heavy metals, and was extracted by $\mathrm{H}_{2} \mathrm{O}$ and $\mathrm{H}_{2} \mathrm{O}_{2}$ after the treatment. Therefore, in this process, supercritical oxidation and extraction coexist. Authors 
concluded that $\mathrm{SC}_{2} \mathrm{O}$ and $\mathrm{H}_{2} \mathrm{O}_{2}$ treatments could not only decompose hazardous organic matters but also effectively detoxify heavy metals in fly ashes.

\section{5.- CONCLUSIONS}

In this review, the interest of SFE not only as an analytical tool but also for process development is discussed. It seems clear from the literature that SFE has an enormous interests nowadays, with more than 200 references dealing with SFE in the last two years (2007-2009). In this review we have tried to widen the range of applications of SFE, including not only its use as sample preparation technique but also new and recent advances in different areas such as food science, pharmaceutical and environmental science. Readers are encouraged to treat the information provided as a tool to develop new processes at lab and pilot scale, to discover new ways for sample preparation, to learn how to deal with SFE optimization and, certainly, to be able to develop in the future emerging technologies able to fulfil the requirements of environmentally clean processes.

Thus, in this review, aspects such as factors that influence the SFE processes (temperature, pressure, enhancement effects, mode of operation, etc.) are discussed using examples. Also, new emerging technologies, for instance the use of supercritical fluids in particle design, sterilization, and separation of enantiomers, among others, are presented.

It seems clear that SFE is now a real option for product development, mainly those that will be used for human consumption, such as new foods, food ingredients/additives or pharmaceutical products. Moreover, SFE has also demonstrated some advantages in the environmental field; for example, to reduce solvent waste, to get new useful compounds from industrial byproducts, and to allow quantification and/or removal of toxic compounds from the environment.

\section{ACKOWLEDGEMENTS.}


Journal of Chromatography A 1217(16): 2495-2511 (2010) http://dx.doi.org/10.1016/j.chroma.2009.12.019

M. H. would like to thank MEC for his Juan de la Cierva contract. This work was supported by an

AGL2008-05108-C03-01 (Ministerio de Educacion y Ciencia) and CSD2007-00063 FUN-C-FOOD

(Programa CONSOLIDER-INGENIO 2010) projects.

\section{REFERENCES}

[1] D. Steytler, in A. Grandison, M. Lewis (Editors), Separation processes in the food and biotechnology industries: Principles and applications, Woodhead Publishing Ltd, Abington (England), 1996.

[2] E. Ramsey, Q. Sun, Z. Zhang, C. Zhang, W. Gou, J. Environ. Sci. 21 (2009) 720.

[3] G. Brunner, J. Food. Eng. 67 (2005) 21.

[4] E. Schütz, Chem. Eng. Technol. 30 (2007) 685.

[5] J.A. Mendiola, M. Herrero, A. Cifuentes, E. Ibáñez, J. Chromatogr. A 1152 (2007) 234.

[6] E. Björklund, C. Sparr-Eskilsson, W. Paul, T. Alan, P. Colin, in P. Worsfold, A.

Townshend, C. Poole (Editors), Encyclopedia of Analytical Science, Elsevier, Oxford (England), 2005, p. 597.

[7] L.S. Daintree, A. Kordikowski, P. York, Advanced Drug Delivery Reviews 60 (2008) 351.

[8] R. Bauza, A. Ríos, M. Valcárcel, Anal. Chim. Acta 391 (1999) 253.

[9] S. Mitra, Sample Preparation Techniques in Analytical Chemistry, John Wiley \& Sons, Inc, Hoboken USA, 2003.

[10] S. Pereda, S.B. Bottini, E.A. Brignole, in J.L. Martínez (Editor), Supercritical fluid extraction of nutraceuticals and bioactive compounds, CRC Press, Taylor \& Francis Group, Boca Raton, USA, 2008.

[11] S. Espinosa, S. Diaz, E.A. Brignole, Computers and Chemical Engineering 24 (2000) 1301.

[12] S. Espinosa, S. Diaz, E.A. Brignole, Ind. Eng. Chem. Res. 41 (2002) 1516.

[13] M. Cismondi, M.S. Diaz, S. Espinosa, E.A. Brignole, Latin American Applied Research 33 (2003) 269.

[14] O. Ferreira, E.A. MacEdo, E.A. Brignole, J. Food. Eng. 70 (2005) 579.

[15] S. Espinosa, M.S. Diaz, E.A. Brignole, J. Supercrit. Fluids 45 (2008) 213.

[16] M.S. Diaz, E.A. Brignole, J. Supercrit. Fluids 47 (2009) 611.

[17] C.G. Pereira, M.A.A. Meireles, Flav. Fragance J. 22 (2007) 407.

[18] M.P. Fernández, J.F. Rodriguez, M.T. García, A. De Lucas, I. Gracia, Ind. Eng. Chem. Res. 47 (2008) 1614.

[19] F. Bianchi, M. Careri, Current Analytical Chemistry 4 (2008) 55.

[20] A. Safaralie, S. Fatemi, A. Salimi, Food Bioprod. Process. doi: 10.1016/j.fbp.2009.02.002 (2009).

[21] S. Liu, F. Yang, C. Zhang, H. Ji, P. Hong, C. Deng, J. Supercrit. Fluids 48 (2009) 9.

[22] L. Wang, B. Yang, X. Du, C. Yi, Food Chem. 108 (2008) 737.

[23] P. Shao, P. Sun, Y. Ying, Food Bioprod. Process. 86 (2008) 227.

[24] G. Liu, X. Xu, Q. Hao, Y. Gao, LWT - Food Sci. Technol. 42 (2009) 1491.

[25] A.L. Oliveira, E.S. Kamimura, J.A. Rabi, Innovative Food Sci. Emerging Technol. 10 (2009) 189.

[26] W. Huang, Z. Li, H. Niu, D. Li, J. Zhang, J. Food. Eng. 89 (2008) 298. 
[27] N. Gelmez, N.S. Kincal, M.E. Yener, J. Supercrit. Fluids 48 (2009) 217.

[28] B. Liu, B. Shen, F. Guo, Y. Chang, Sep. Purif. Technol. 64 (2008) 242.

[29] T. Fornari, L. Vázquez, C.F. Torres, E. Ibáñez, F.J. Señoráns, G. Reglero, J. Supercrit. Fluids 45 (2008) 206.

[30] L. Fiori, J. Supercrit. Fluids 50 (2009) 218.

[31] T. Fornari, C.F. Torres, F.J. Señoránns, G. Reglero, AIChE J. 55 (2009) 1023.

[32] S. Machmudah, M. Kondo, M. Sasaki, M. Goto, J. Munemasa, M. Yamagata, J. Supercrit. Fluids 44 (2008) 301.

[33] L. Fiori, D. Basso, P. Costa, J. Supercrit. Fluids 47 (2008) 174.

[34] J. Shi, M. Khatri, S.J. Xue, G.S. Mittal, Y. Ma, D. Li, Sep. Purif. Technol. 66 (2009) 322.

[35] B. Nagy, B. Simandi, J. Supercrit. Fluids 46 (2008) 293.

[36] M.G. Bernardo-Gil, M. Casquilho, AIChE J. 53 (2007) 2980.

[37] L. Wang, Y. Chen, Y. Song, Y. Chen, X. Liu, J. Sep. Sci. 31 (2008) 3238.

[38] X. Liu, M. Zhao, J. Wang, W. Luo, J. Food Biochem. 33 (2009) 307.

[39] E.M.Z. Michelin, A.A. Salvador, C.A.S. Riehl, A. Smania, E.F.A. Smania, S.R.S. Ferreira, Biores. Technol. 100 (2009) 6615

[40] A. Safaralie, S. Fatemi, F. Sefidkon, J. Chromatogr. A 1180 (2008) 159.

[41] H.H. Mirzaei, M.H. Meshkatalsadat, S. Soheilivand, J. Appl. Sci. 7 (2007) 2535-2538

[42] E. Ghasemi, Y. Yamini, N. Bahramifar, F. Sefidkom, J. Food Eng. 79 (2007) 306

[43] A.H. Al-Marzougi, M.V. Rao, B. Jobe. J. Liq. Chromatogr. Rel. Technol. 30 (2007) 463

[44] M. Pinelo, A. Ruiz-Rodríguez, J. Sineiro, F.J. Señoráns, G. Reglero, M.J. Núñez, European Food Research and Technology 226 (2007) 199.

[45] M. Zougagh, A. Ríos, Electrophoresis 29 (2008) 3213.

[46] E. Ziémons, V. Barillaro, E. Rozet, N.W. Mbakop, R. Lejeune, L. Angenot, L. Thunus, P. Hubert, Talanta 71 (2007) 911.

[47] E. Ziemons, N.W. Mbakop, E. Rozet, R. Lejeune, L. Angenot, L. Thunus, P. Hubert, J. Supercrit. Fluids 40 (2007) 368.

[48] T. Hyötyläinen, J. Chromatogr. A 1186 (2008) 39.

[49] T. Hyötyläinen, J. Chromatogr. A 1153 (2007) 14.

[50] L.A.V. Sarmento, R.A.F. Machado, J.C.C. Petrus, T.R. Tamanini, A. Bolzan, J. Supercrit. Fluids 45 (2008) 64.

[51] F. Montañés, T. Fornari, P.J. Martín-Álvarez, A. Montilla, N. Corzo, A. Olano, E. Ibáñez, J. Supercrit. Fluids 41 (2007) 61.

[52] F. Montañés, N. Corzo, A. Olano, G. Reglero, E. Ibáñez, T. Fornari, J. Supercrit. Fluids 45 (2008) 189.

[53] F. Montañés, A. Olano, G. Reglero, E. Ibáñez, T. Fornari, Sep. Purif. Technol. 66 (2009) 383.

[54] F. Montañés, T. Fornari, R.P. Stateva, A. Olano, E. Ibáñez, J. Supercrit. Fluids 49 (2009) 16.

[55] S.M. Ghoreishi, G.R. Shahrestani, H.S. Ghaziaskar, Chem. Eng. Technol. 32 (2009) 45.

[56] M. Eisenmenger, N.T. Dunford, J. Am. Oil Chem. Soc. 85 (2008) 55

[57] A.B.A. de Azevedo, T.G. Kieckbush, A.K. Tashima, R.S. Mohamed, P. Mazzafera, S.A.B. Vieira de Melo, J. Supercrit. Fluids 44 (2008) 186

[58] C.R. Chen, C.H. Wang, L.Y. Wang, Z.H. Hong, S.H. Chen, W.J. Ho, C.M.J. Chang, J. Supercrit. Fluids, 45 (2008) 322

[59] R. Davarnejad, K.M. Kassim, A. Zainal, S.A. Sata, J. Food Eng. 89 (2008) 472

[60] W.J. Kim, J.D. Kim, J. Kim, S.G. Oh, Y.W. Lee, J. Food Eng. 89 (2008) 303-309

[61] H. Abbasi, K. Rezaei, L. Radishi. J. Am. Che. Soc. 85 (2008) 83

[62] M.L. Martínez, M.A. Mattea, D.M. Maestri, J. Food Eng. 88 (2008) 399-404

[63] Y. Sanchez-Vicente, A. Cabañas, J.A.R. Renuncio, C. Pando, J. Supercrit. Fluids, 49 (2009) 167-173 
[64] S.B. Glisic, D.R. Misic, ;.D. Stamenic, I.T. Zizovic, R.M. Asamin, D.U. Skala, Food Chem. 105 (2007) 346

[65] P. Mitra, G.S. Ramaswamy, K.S. Chang, J. Food Eng. 95 (2009) 208-213

[66] M. Bravi, F. Spinoglio, N. Verdone, N. Adami, A. Aliboni, A. D’Andrea, A. De Santis, D. Ferri. J. Food Eng. 78 (2007) 488

[67] J. Shi, C. Yi, X. Ye, S. Xue, Y. Jiang, Y. Ma, D. Liu, LTW-Food Sci. Technol. 2009 in press doi:10.1016/j.lwt.2009.07.003

[68] Y.B. Zuo, A.W. Zeng, X.G. Yuan, K.T. Yu, J. Food Eng. 89 (2008) 384-389

[69] J.M.A. Araujo, M.V. Silva, J.B.P. Chaves, Food Chem. 105 (2007) 266

[70] J. Yu, Y.F. Liu, A.Y. Qiu, X.G. Wang, LTW-Food Sci. Technol. 40 (2007) 800-806

[71] Y. Kong, Y.J. Fu, Y.G. Zu, W. Liu, W. Wang, X. Hue, M. Yang, Food Chem. 117 (2009) 152-159

[72] C.R. Chen, Y.N. Lee, M.R. Lee, C.M.J. Chang, J Taiwan Inst. Chem. Eng. 40 (2009) 130

[73] M. Nakornriab, T. Sriseadka, S. Wongpornchai, J. Food Lip. 15 (2008) 488-503

[74] G. Perretti, A. Motori, E. Bravi, F. Favati, L. Montanari, P. Fantozzi, J. Supercrit. Fluids 40 (2007) 349-353

[75] L.H. Chang, C.T. Shen, S.J. Hsieh, S.L. Hsu, H.C. Chang, C.M.J. Chang, Sep. Purif. Technol. 64 (2008) 213

[76] S. Espinosa, M.S. Díaz, E.A. Brignole, J. Supercrit. Fluids, 45 (2008) 213

[77] H. Aro, E.P. Jarvenpaa, K. Konko, M. Sihvonen, V. Hietaniemi, R. Huopalahti. Eur. Food Res. Technol. 228 (2009) 857

[78] A.J. Spence, R. Jimenez-Flores, M. Qian, L. Doddik, J. Dairy Sci. 92 (2009) 2373-2381

[79] C.F. Torres, G. Torrelo, F.J. Señoráns, G. Reglero, J. Dairy Sci. 82 (2009) 1840-1845

[80] O.J. Catchpole, S.J. Tallon, J.B. Grey, K. Fletcher, A.J. Fletcher, The Journal of Supercritical Fluids 45 (2008) 314.

[81] C.P. Passos, R.M. Silva, F.A. Da Silva, M.A. Coimbra, C.M. Silva. J. Supercrit. Fluids, 48 (2009) 225-229

[82] C.F. Torres, T. Fornari, G. Torrelo, F.J. Señoráns, G. Reglero, Eur. J. Lipid Sci. Technol. 111 (2009) 459-463

[83] Q.A. Zhang, X.H. Fan, Z.Q. Zhang, B.S. Zhang, Z.Q. Zhang, X.Y. Jia, LTW Food Sci. Technol. 42 (2009) 1530-1537

[84] I. Gracia, J.F. Rodríguez, M.T. García, A. Álvarez, A. García, J. Supercrit. Fluids, 43 (2007) $37-42$

[85] T. Fornari, E.J. Hernandez, A.Ruiz-Rodriguez, F.J. Señorans, G. Reglero, J. Supercrit. Fluids, 50 (2009) 91

[86] J.L. Bernal, M.J. Nozal, L. Toribio, C. Diego, R. Mayo, R. Maestre. J. Chromatogr. A 1192 (2008) 266

[87] G. Perretti, in C. Turner (Editor), Modern Extraction Techniques, American Chemical Society, Washington, DC, 2006, p. 23.

[88] J.J. Wu, J.C. Lin, C.H. Wang, T.T. Jong, H.L. Yang, S.L. Hsu, C.m.J. Chang, J. Supercrit. Fluids 50 (2009) 33.

[89] E. Vági, B. Simándi, K.P. Vásárhelyiné, H. Daood, A. Kéry, F. Doleschall, B. Nagy, J. Supercrit. Fluids 40 (2007) 218.

[90] L.S. Kassama, J. Shi, G.S. Mittal, Sep. Purif. Technol. 60 (2008) 278.

[91] L. Ciurlia, M. Bleve, L. Rescio, J. Supercrit. Fluids 49 (2009) 338.

[92] D. Cossuta, B. Simandi, J. Hohmann, F. Doleschall, T. Keve, J. Sci. Food. Agric. 87 (2007) 2472 .

[93] H.L.N. Lau, Y.M. Choo, A.N. Ma, C.H. Chuah, J. Food Eng. 84 (2008) 298-296

[94] N. Rubio-Rodriguez, S.M. de Diego, S. Beltran, I. Jaime, M.T. Sanz, J. Rovira. J. Supercrit. Fluids, 47 (2008) 215-226 
[95] A. de Lucas, A. García, A. Alvarez, I. Gracia, J. Supercrit. Fluids, 41 (2007) 267

[96] H. Abbasi, K. Rezaei, Z. Emamdjomeh, S.M. Ebrahimzadeh Mousavi. Eur. J. Lipid Sci. TEchnol. 110 (2008) 435

[97] Y. Kawahito, M. Kondo, S. Machmudah, K. Sibano, M. Sasaki, M. Goto. Sep. Purif. Technol. 61 (2008) 130-135

[98] Içen, H., Gürü, M., J. Supercrit. Fluids, 50 (2009) 225-228

[99] C.E. Schwarz, I. Nieuwoudt, J.H. Knoetze, Ind. Eng. Chem. Res. 46 (2007) 1780.

[100] H.L.L. Nang, Y.M. Choo, A.N. Ma, C.H. Chuah, American Journal of Environmental Sciences 3 (2007) 54.

[101] A. Weber, E.H. Lee, S.K. Shin, B.S. Chun, Chem. Eng. Technol. 30 (2007) 732.

[102] C.S. Tan, P.L. Lee, Environ. Sci. Technol. 42 (2008) 2150.

[103] K. Okuda, S. Ohara, M. Umetsu, S. Takami, T. Adschiri, Bioresour. Technol. 99 (2008) 1846.

[104] M. Dong, T.H. Walker, Bioresour. Technol. 99 (2008) 8504.

[105] Y. Yang, A. Gilbert, C. Xu, AIChE J. 55 (2009) 807.

[106] J.L. Leazer Jr, S. Gant, A. Houck, W. Leonard, C.J. Welch, Environ. Sci. Technol. 43 (2009) 2018.

[107] Z.J. Wei, A.M. Liao, H.X. Zhang, J. Liu, S.T. Jiang, Bioresour. Technol. 100 (2009) 4214.

[108] M.E.M. Braga, R.M.S. Santos, I.J. Seabra, R. Facanali, M.O.M. Marques, H.C. de Sousa, J. Supercrit. Fluids 47 (2008) 37.

[109] A.R.B. de Quiros, H.S. Costa, J. Food Compos. Anal. 19 (2006) 97

[110] J.T. Landrum, R.A. Bone, M.D. Kilburn, Int. J. Vitam. Nutr. Res. 61 (1991) 277

[111] M.D. Snodderly, Am. J. Clin. Nutr. 62 (1995) 1448

[112] A.O. Omoni, R.E. Aluko, Trends Food Sci. Technol. 16 (2005) 344

[113] J. Shi, C. Yi, S.J. Xue, Y. Jiang, Y. Ma, D. Li, J. Food. Eng. 93 (2009) 431.

[114] B.P. Nobre, A.F. Palavra, F.L.P. Pessoa, R.L. Mendes, Food Chem. 116 (2009) 680.

[115] I.S.M. Zaidul, N.A. Nik Norulaini, A.K. Mohd Omar, R.L. Smith, J. Food Eng. 79 (2007) 1007-1014

[116] T. Fang, M. Goto, X. Wang, X. Ding, J. Geng, M. Sasaki, T. Hirose, J. Supercrit. Fluids, 40 (2007) 50

[117] D. Wen, H. Jiang, K. Zhang, Prog. Nat. Sci. 19 (2009) 273.

[118] Y. Sun, Z. Liu, J. Wang, W. Tian, H. Zhou, L. Zhu, C. Zhang, Sep. Purif. Technol. 64 (2008) 221.

[119] M.T. Liang, C.H. Yang, S.T. Li, C.S. Yang, H.W. Chang, C.S. Liu, T.M. Cham, L.Y. Chuang. Eur. Food Res. Technol. 227 (2008) 1387-1396

[120] Y. Zhang, D. Wei, S. Guo, X. Zhang, M. Wnag, F. Chen. J. Food Lip. 14 (2007) 411-423

[121] P. Mitra, P. C. Barman, K. S. Chang. Food Bioprocess. Technol. (2009) in press, DOI: 10.1007/s11947-008-0179-2

[122] S. Hamdam, H.G. Daood, M. Toth-Markus, V. Illes. J. Supercrit. Fluids 44 (2008) 25-30

[123] N. A. Alhaj, M.N. Shamsudin, H.F. Zamri, R. Abdullah. Am. J. Pharm. Toxicol. 3 (2008) 225

[124] P. Iheozor-Ejiofor, E. Szwajcer Dey. J. Supercrit. Fluids, 50 (2009) 19-32

[125] Y. Zhannan, L. Shiqiong, P. Quancai, Z. Chao, Y. Zhengweng. Chromatographia, 69 (2009) 785-790

[126] L. Huang, T. Zhong, T. Chen, Z. Ye, G. Chen. Rapid Commun. Mass Spectrom. 21 (2007) 3024-3032

[127] A. Salimi, S. Fatemi, H.Z. Nei Nei, A. Safaralie, Chem. Eng. Technol. 31 (2008) 1470-1480

[128] A. Erkucuk, I.H. Akgun, O. Yesil-Celiktas, J. Supercrit. Fluids, 2009 in press, doi:10.1016/j.supflu.2009.07.002 
[129] C. Grosso, V. Ferraro, A.C. Figueiredo, J.G. Barroso, J.A. Coelho, A.M. Palavra. Food Chem. 111 (2008) 197-203

[130] C.R. Piantino, F.W.B. Aquino, L.A. Follegatti-Romero, F.A. Cabral. J. Supercrit. Fluids 47 (2008) 209-214

[131] I. Zizovic, M. Stamenic, J. Ivanovic, A. Orlovic, M. Ristic, S. Djordjevic, S.D. Petrovic, D. Skala. J. Supercrit. Fluids 43 (2007) 249-258

[132] C. Soto, E. Conde, A. Moure, M.E. Zúñiga, H. Domínguez, Eur. J. Lipid. Sci. Technol. 110 (2008) 1035-1044

[133] Q. Chen, S. Yao, X. Huang, J. Luo, J. Wang, L. Kong, Food Chem. 117 (2009) 504

[134] P. Kotnik, M. Skerget, Z. Knez. J. Supercrit. Fluids, 43 (2007) 192-198

[135] D. Cossuta, B. Simandi, E. Vagi, J. Hohmann, A. Prechl, E. Lemberkovics, A. Kery, T. Keve, J. Supercrit. Fluids, 47 (2008) 188

[136] E. Langa, J. Cacho, A.M.F. Palavra, J. Burillo, A.M. Mainar, J.S. Urieta, J. Supercrit. Fluids, 49 (2009) 37-44

[137] J. Li, M. Zhang, T. Zheng, Food Chem. 115 (2009) 939-944

[138] G. Filho, V.V. de Rosso, M.A.A. Meireles, P.T.V. Rosa, A.L. Oliveira, A.Z. Mercadante, F.A. Cabral. J. Supercrit. Fluids, 46 (2008) 33

[139] A.S. Zarena, K. Udaya Sankar. J. Supercrit. Fluids 49 (2009) 330-337

[140] L. Casas, C. Mantell, M. Rodríguez, A. Torres, F.A. Macías, E. Martínez de la Ossa, Chem. Eng. J. 152 (2009) 301.

[141] L. Casas, C. Mantell, M. Rodriguez, A. Torres, F.A. Macias, E.J. Martinez de la Osa, J. Supercrit. Fluids, 45 (2008) 37

[142] H. Kazazi, K. Rezaei, S.J. Ghotb-Sharif, Z. Emam-Djomeh, Y. Yamini, Food Chem. 105 (2007) 805-811

[143] O. Yesil-Celiktas, F. Otto, H. Parlar, Eur. Food Res. Technol. 229 (2009) 671-677

[144] S. Machmudah, Y. Kawahito, M. Sasaki, M. Goto. J. Supercrit. Fluids 44 (2008) 308-314

[145] S. Machmudah, Y. Kawahito, M. Sasaki, M. Goto. J. Supercrit. Fluids 41 (2007) 3421-428

[146] K.W. Chan, M. Ismail. Food Chem. 114 (2009) 970

[147] S.A. Aleksovski, H. Sovova, J. Supercrit. Fluids 40 (2007) 239

[148] J.A. Coelho, C. Grosso, A.P. Pereira, J. Burillo, J.S. Urieta, A.C. Figueiredo, J.G. Barroso, R.L. Mendes, A.M. Palavra. Flavour Fragr. J. 22 (2007) 438

[149] A.T. de Souza, T.L. Benazzi, M.B. Grings, V. Cabral, E.A. da Silva, L. Cardozo-Filho, O.A. Ceva Antunes, J. Supercrit. Fluids 47 (2008) 182

[150] E. Talansier, M.E.M. Braga, P.T.V. Rosa, D. Paolucci-Jeanjean, M.A.A. Meireles. J. Supercrit. Fluids, 47 (2008) 200-208

[151] T. Ćebović, S. Spasić, M. Popović, Phytother. Res. 22 (2008) 1097.

[152] D.C. Soares, C.G. Pereira, M.Â.A. Meireles, E.M. Saraiva, Parasitology International 56 (2007) 135.

[153] D. Šmidling, D. Mitić-Ćulafić, B. Vuković-Gačćić, D. Simić, J. Knežević-Vukčević, Archives of Biological Sciences 60 (2008) 421.

[154] N.K. Upadhyay, R. Kumar, S.K. Mandotra, R.N. Meena, M.S. Siddiqui, R.C. Sawhney, A. Gupta, Food Chem. Toxicol. 47 (2009) 1146.

[155] M. Basu, R. Prasad, P. Jayamurthy, K. Pal, C. Arumughan, R.C. Sawhney, Phytomedicine 14 (2007) 770.

[156] Y. Zhang, X. Yao, B. Bao, Y. Zhang, Phytother. Res. 20 (2006) 872.

[157] M. Herrero, A. Cifuentes, E. Ibáñez. Food Chem. 98 (2006) 136-148

[158] M. Plaza, M. Herrero, A. Cifuentes, E. Ibáñez. J. Agric. Food Chem. 57 (2009) 7159-7170

[159] L. Jaime, J.A. Mendiola, E. Ibañez, P.J. Martin-Alvarez, A. Cifuentes, G. Reglero, F.J. Señorans, J. Agric. Food Chem. 55 (2007) 10585. 
[160] M.D. Macías-Sánchez, C. Mantell, M. Rodríguez, E. Martínez de la Osa, L.M. Lubián, O. Montero. Talanta, 77 (2009) 948-952

[161] M.D. Macías-Sánchez, C. Mantell, M. Rodríguez, E. Martínez de la Osa, L.M. Lubián, O. Montero. J. Sep. Sci. 31 (2008) 1352-1362

[162] M.D. Macías-Sánchez, C. Mantell, M. Rodríguez, E. Martínez de la Osa, L.M. Lubián, O. Montero. J. Supercrit. Fluids 39 (2007) 323-329

[163] M. El Hattab, G. Culioli, L. piovellt, S.E. Chitour, R. Valls, J. Chromatogr. A 1143 (2007) 1

[164] Q. Hu, B. Pan, J. Xu, J. Shen, Y. Shi, J. Food Eng. 80 (2007) 997-1001

[165] Z. Wu, S. Wu, X. Shi. J. Food Process Eng. 30 (2007) 174-185

[166] L. Gouveia, B.P. Nobre, F.M. Marcelo, S. Mrejen, M.T. Cardoso, A.F. Palavra, R.L. Mendes, Food Chem. 101 (2007) 717-723

[167] J.A. Mendiola, D. García-Martínez, F.J. Rupérez, P.J. Martín-Álvarez, G. Reglero, A. Cifuentes, C. Barbas, E. Ibáñez, F.J. Señoráns, J. Supercrit. Fluids 43 (2008) 484.

[168] J.A. Mendiola, L. Jaime, S. Santoyo, G. Reglero, A. Cifuentes, E. Ibáñez, F.J. Señoráns, Food Chem. 102 (2007) 1357.

[169] M.G. Sajilata, R.S. Singhal, M.Y. Kamat, Food Chem. 109 (2008) 580.

[170] M.G. Sajilata, R.S. Singhal, M.Y. Kamat, J. Food. Eng. 84 (2008) 321.

[171] F.B. Metting, J. Ind. Microbiol. 17 (1996) 477-489

[172] M.D. Macías-Sánchez, C. Mantell Serrano, M. Rodríguez Rodriguez, E. Martinez de la Ossa, Chem. Eng. J. 150 (2009) 104-113

[173] F.J. Rupérez, D. García-Martínez, B. Baena, N. Maeso, M. Vallejo, S. Angulo, A. García, E. Ibáñez, F.J. Señorans, A. Cifuentes, C. Barbas, J. Pharm. Biomed. Anal. 49 (2009) 786.

[174] M. Herrero, L. Jaime, P.J. Martin-Álvarez, A. Cifuentes, E. Ibáñez, J. Agric. Food Chem. 54 (2006) 5597.

[175] M. Herrero, E. Ibáñez, A. Cifuentes, G. Reglero, S. Santoyo, J. Food Prot. 69 (2006) 2471.

[176] J.A. Mendiola, S. Santoyo, A. Cifuentes, G. Reglero, E. Ibáñez, F. Javier Señoráns, J. Food Prot. 71 (2008) 2138.

[177] C.G. Pereira, M.O.M. Marques, A.S. Barreto, A.C. Siani, E.C. Fernandes, M.A.A. Meireles, The Journal of Supercritical Fluids 30 (2004) 51.

[178] P. York, U.B. Kompella, B.Y. Shekunov, Supercritical Fluid Technology for Drug Product Development, Marcel Dekker, New York, USA, 2004.

[179] I. Pasquali, R. Bettini, Int. J. Pharm. 364 (2008) 176.

[180] K. Byrappa, S. Ohara, T. Adschiri, Advanced Drug Delivery Reviews 60 (2008) 299.

[181] L.A. Meure, N.R. Foster, F. Dehghani, AAPS PharmSciTech 9 (2008) 798.

[182] M. Ashraf-Khorassani, L.T. Taylor, K.C. Waterman, P. Narayan, D.R. Brannegan, G.L. Reid, Pharm. Dev. Technol. 10 (2005) 507.

[183] E.L. Izake, J. Pharm. Sci. 96 (2007) 1659.

[184] B. Simándi, S. Keszei, E. Fogassy, J. Sawinsky, J. Org. Chem. 62 (1997) 4390.

[185] R. Bauza, A. Ríos, M. Valcárcel, Sep. Sci. Technol. 39 (2004) 459.

[186] A. Kordikowski, P. York, D. Latham, J. Pharm. Sci. 88 (1999) 786.

[187] S. Keszei, B. Simándi, E. Szekely, E. Fogassy, J. Sawinsky, S. Kemany, Tetrahedron Asymmetry 10 (1999) 1275.

[188] P. Molnár, P. Thorey, G. Bánsághi, E. Székely, L. Poppe, A. Tomin, S. Kemény, E. Fogassy, B. Simándi, Tetrahedron Asymmetry 19 (2008) 1587.

[189] I. Kmecz, B. Simándi, E. Székely, J. Lovász, E. Fogassy, Chirality 19 (2007) 430.

[190] A. Rajendran, G. Paredes, M. Mazzotti, J. Chromatogr. A 1216 (2009) 709.

[191] L.T. Taylor, J. Supercrit. Fluids 47 (2009) 566.

[192] T.Q. Yan, C. Orihuela, D. Swanson, Chirality 20 (2008) 139.

[193] W.N. Mack, S.G. Sunol, A.K. Sunol, in AIChE Annual Meeting, Conference Proceedings, 2005, p. 1534. 
[194] K.H. Gahm, H. Tan, J. Liu, W. Barnhart, J. Eschelbach, S. Notari, S. Thomas, D. Semin, J. Cheetham, J. Pharm. Biomed. Anal. 46 (2008) 831.

[195] R.A. Coe, J.O. Rathe, J.W. Lee, J. Pharm. Biomed. Anal. 42 (2006) 573.

[196] C. Leuner, J. Dressman, Eur. J. Pharm. Biopharm. 50 (2000) 47.

[197] R. Thiering, F. Dehghani, N.R. Foster, J. Supercrit. Fluids 21 (2001) 159.

[198] F. Chiellini, A.M. Piras, C. Errico, E. Chiellini, Nanomedicine 3 (2008) 367.

[199] S.P. Cape, J.A. Villa, E.T.S. Huang, T.H. Yang, J.F. Carpenter, R.E. Sievers, Pharm. Res. 25 (2008) 1967.

[200] K. Wu, J. Li, W. Wang, D.A. Winstead, J. Pharm. Sci. 98 (2009) 2422.

[201] S. Salmaso, S. Bersani, N. Elvassore, A. Bertucco, P. Caliceti, Int. J. Pharm. doi: 10.1016/j.ijpharm.2009.06.014 (In press,).

[202] S. Salmaso, N. Elvassore, A. Bertucco, P. Caliceti, J. Pharm. Sci. 98 (2009) 640.

[203] Y.H. Kim, C. Sioutas, K.S. Shing, Pharm. Res. 26 (2009) 61.

[204] J. Chu, G. Li, K.H. Row, H. Kim, Y.W. Lee, Int. J. Pharm. 369 (2009) 85.

[205] A. Rouholamini Najafabadi, A. Vatanara, K. Gilani, M. Rafiee Tehrani, Daru 13 (2005) 1.

[206] A. Vatanara, A. Rouholamini Najafabadi, K. Gilani, R. Asgharian, M. Darabi, M. RafieeTehrani, Daru 17 (2009) 6.

[207] L.Y. Lee, C.H. Wang, K.A. Smith, J. Controlled Release 125 (2008) 96.

[208] P.A. Charpentier, M. Jia, R.A. Lucky, AAPS PharmSciTech 9 (2008) 39.

[209] A.M. Barrett, F. Dehghani, N.R. Foster, Pharm. Res. 25 (2008) 1274.

[210] J. Chingunpitak, S. Puttipipatkhachorn, Y. Tozuka, K. Moribe, K. Yamamoto, Drug Dev. Ind. Pharm. 34 (2008) 609.

[211] H. Hong, Q. Suo, F. Li, X. Wei, J. Zhang, Chem. Eng. Technol. 31 (2008) 1051.

[212] A. Argemí, A. López-Periago, C. Domingo, J. Saurina, J. Pharm. Biomed. Anal. 46 (2008) 456.

[213] S. Shimpi, B. Chauhan, P. Shimpi, Acta Pharmaceutica 55 (2005) 139.

| [214] H.A. Hassan, A.H. Al-Marzouqi, B. Jobe, A.A. Hamza, G.A. Ramadan, J. Pharm. Biomed. Anal. 45 (2007) 243.

[215] A.H. Al-Marzouqi, H.M. Elwy, I. Shehadi, A. Adem, J. Pharm. Biomed. Anal. 49 (2009) 227.

[216] A. Semalty, M. Semalty, B.S. Rawat, D. Singh, M.S.M. Rawat, Expert Opinion on Drug Delivery 6 (2009) 599.

[217] Y. Li, D.J. Yang, S.L. Chen, S.B. Chen, A.S.C. Chan, Pharm. Res. 25 (2008) 563.

[218] M.D.A. Saldaña, V. Nagpal, S.E. Guigard, Environmental Technology 26 (2005) 1013.

[219] J. Sunarso, S. Ismadji, J. Hazard. Mater. 161 (2009) 1.

[220] N. Fidalgo-Used, E. Blanco-González, A. Sanz-Medel, Anal. Chim. Acta 590 (2007) 1.

[221] T. Miyawaki, A. Kawashima, K. Honda, Chemosphere 70 (2008) 648.

[222] S.A. Smyth, L. Lishman, M. Alaee, S. Kleywegt, L. Svoboda, J.J. Yang, H.B. Lee, P. Seto, Chemosphere 67 (2007) 267.

[223] R. Rodil, A.M. Carro, R.A. Lorenzo, R. Cela, Chemosphere 67 (2007) 1453.

[224] J.-H. Choi, M.I.R. Mamun, A.M.A. El-Aty, K.T. Kim, H.-B. Koh, H.-C. Shin, J.-S. Kim, K.B. Lee, J.-H. Shim, Talanta 78 (2009) 348.

[225] C. Zhao, L. Bai, H. Li, F. Li, C. Xin, Arch. Pharm. Res. 30 (2007) 1558.

[226] C. Barba, M.M. Calvo, M. Herraiz, G. Santa-María, Food Chem. 114 (2009) 1517.

[227] J.P. Kreitinger, A. Quiñones-Rivera, E.F. Neuhauser, M. Alexander, S.B. Hawthorne, Environ. Toxicol. Chem. 26 (2007) 1809.

[228] M. Boulaid, A. Aguilera, V. Busonera, F. Camacho, A.V. Monterreal, A. Valverde, J. Environ. Sci. Health. B. 42 (2007) 809.

[229] B.T. Bogolte, G.A.C. Ehlers, R. Braun, A.P. Loibner, European Journal of Soil Biology 43 (2007) 242. 
[230] V. Leonardi, V. Šašek, M. Petruccioli, A. D'Annibale, P. Erbanova, T. Cajthaml, Int. Biodet. Biodeg. 60 (2007) 165.

[231] R. Westbom, S. Josefsson, L. Mathiasson, E. Bjorklund, Int. J. Environ. Anal. Chem. 87 (2007) 259.

[232] L.C. Mmualefe, N. Torto, P. Huntsman-Mapila, B. Mbongwe, Water SA 34 (2008) 405.

[233] Y. Yang, T. Cajthaml, T. Hofmann, Environ. Pollut. 156 (2008) 745.

[234] K.K. Jessing, T. Bowers, B.W. Strobel, B. Svensmark, H.C.B. Hansen, Int. J. Environ. Anal. Chem. 89 (2009) 1.

[235] M.A. Lage-Yusty, S. Alvarez-Pérez, M.O. Punín-Crespo, Bull. Environ. Contam. Toxicol. 82 (2009) 158.

[236] A.M. Abd El-Aty, J.H. Choi, M.W. Ko, S. Khay, A. Goudah, H.C. Shin, J.S. Kim, B.J. Chang, C.H. Lee, J.H. Shim, Anal. Chim. Acta 631 (2009) 108.

[237] A. Kawashima, S. Watanabe, R. Iwakiri, K. Honda, Chemosphere 75 (2009) 788.

[238] M. Faisal, Y. Atsuta, H. Daimon, K. Fujie, Asia-Pacific Journal of Chemical Engineering 3 (2008) 364.

[239] J.S. Wang, K. Chiu, J. Hazard. Mater. 158 (2008) 384.

[240] P. Kumar, A. Pal, M.K. Saxena, K.L. Ramakumar, Radiochim. Acta 95 (2007) 701.

[241] M. Koh, J. Yoo, M. Ju, B. Joo, K. Park, H. Kim, H. Kim, B. Fournel, Ind. Eng. Chem. Res. 47 (2008) 278.

[242] R.D. Weinstein, J.G. Richard, C.A. Bessel, W.H. Hanlon, D.W. Skaf, Chem. Eng. Technol. 31 (2008) 575.

[243] W.L. Chou, K.C. Yang, J. Hazard. Mater. 154 (2008) 498.

[244] W.L. Chou, C.T. Wang, K.C. Yang, Y.H. Huang, J. Hazard. Mater. 160 (2008) 6.

[245] G. Tian, W. Liao, C.M. Wai, L. Rao, Ind. Eng. Chem. Res. 47 (2008) 2803.

[246] M. Gavrilescu, L.V. Pavel, I. Cretescu, J. Hazard. Mater. 163 (2009) 475.

[247] B. Veriansyah, J.D. Kim, Y.W. Lee, J. Cleaner. Prod. 15 (2007) 972.

[248] D. Bo, F.S. Zhang, L. Zhao, J. Hazard. Mater. 170 (2009) 66.

[249] J. Guo, J. Guo, Z. Xu, J. Hazard. Mater. 168 (2009) 567.

[250] F.R. Xiu, F.S. Zhang, J. Hazard. Mater. 170 (2009) 191. 
Journal of Chromatography A 1217(16): 2495-2511 (2010) http://dx.doi.org/10.1016/j.chroma.2009.12.019

\section{FIGURE CAPTIONS}

Figure 1.- Scheme of a SFE-CE online coupling apparatus: M. Zougagh, A. Ríos "Supercritical fluid extraction as an on-line clean-up technique for determination of riboflavin vitamins in food samples by capillary electrophoresis with fluorimetric detection" Electrophoresis 29 (2008) 3213. Copyright Wiley-VCH Verlag GmbH \& Co. KGaA. Reproduced with permission.

Figure 2.- Scheme of the typical supercritical antisolvent precipitation equipment 
Journal of Chromatography A 1217(16): 2495-2511 (2010) http://dx.doi.org/10.1016/j.chroma.2009.12.019

Table 1.-. Summary of the works published on the recovery of valuable compounds from industrial by-products using SFE in the period 2007-

2009

\begin{tabular}{|c|c|c|c|c|c|}
\hline Matrix & Compounds & Extraction conditions & Other features & Analytical technique & Ref. \\
\hline Rice wine lees & Polyphenols & $\mathrm{CO}_{2}, 80$ bar, $30^{\circ} \mathrm{C}$ & $\begin{array}{l}\text { Antioxidant activity measurement: DPPH. } \\
\text { Comparison with Soxhlet }\end{array}$ & UV Spectrometry & [88] \\
\hline \multirow{2}{*}{ Tomato } & Tocopherols and phytosterols & $\mathrm{CO}_{2}, 300 \mathrm{bar}, 40^{\circ} \mathrm{C}$ & Full factorial response surface experimental design & $\begin{array}{l}\text { HPLC-DAD }(290,320 \text { and } 360 \\
\text { nm), GC-FID }\end{array}$ & [89] \\
\hline & Lycopene & $\mathrm{CO}_{2}+$ Cosolvents, $250-450 \mathrm{bar}, 40-70^{\circ} \mathrm{C}$ & Central composite rotatable design & HPLC-DAD $(460 \mathrm{~nm})$ & [90] \\
\hline Tomato \& hazelnuts & Lycopene and essential oils & $\mathrm{CO}_{2}, 400$ bar, $60^{\circ} \mathrm{C}$ & -- & HPLC-UV (C30 stationary phase) & [91] \\
\hline Sea bucktorn & Carotenoids and tocopherols & $\mathrm{CO}_{2}, 300-460$ bar, $40-90{ }^{\circ} \mathrm{C}$ & Full factorial response surface experimental design & $\begin{array}{l}\text { TLC, HPLC-FLD (Ex. 295nm, EM. } \\
330 \mathrm{~nm})\end{array}$ & [92] \\
\hline $\begin{array}{c}\text { Palm-pressed mesocarp } \\
\text { fiber }\end{array}$ & Sterols, carotenoids and tocopherols & $\mathrm{CO}_{2}, 100-300$ bar, $40^{\circ} \mathrm{C}$ & Continuous extraction $1-6 \mathrm{~h}$ & GC-FID, HPLC-DAD & [93] \\
\hline Hake by-products & PUFA's & $\mathrm{CO}_{2}, 250 \mathrm{bar}, 40^{\circ} \mathrm{C}$ & $\begin{array}{c}\text { Freeze dried, Antioxidant activity measurement: } \\
\text { TBARS }\end{array}$ & GC-FID & [94] \\
\hline Sugar cane crude wax & Long chain $n$-alcohols & $\mathrm{CO}_{2}, 300-350$ bar, $50-100^{\circ} \mathrm{C}$ & Full factorial response surface experimental design & GC-FID & [95] \\
\hline Pomegranate seeds & Polyphenols & $\mathrm{CO}_{2}, 130-470$ bar, $40-70{ }^{\circ} \mathrm{C}$ & Central composite rotatable design & GC-FID, HPLC-UC (292 nm) & {$[24,96]$} \\
\hline Loquat seeds & Phytosterols & $\mathrm{CO}_{2}, 200-450 \mathrm{bar}, 40-80^{\circ} \mathrm{C}$ & Comparison with Soxhlet & HPLC-DAD $(210 \mathrm{~nm})$ & [97] \\
\hline Tea stalk & Caffeine & $\mathrm{CO}_{2}, 200$ bar, $55^{\circ} \mathrm{C}$ & -- & HPLC-UV (272 nm) & {$[98]$} \\
\hline Wax derivatives & Alcohol ethoxylates & Water and Toluene, 130 bar, $120^{\circ} \mathrm{C}$ & -- & GC, GPC, TOC & {$[99]$} \\
\hline $\begin{array}{l}\text { Fresh palm-pressed } \\
\text { fiber }\end{array}$ & Water-soluble compounds & $\mathrm{CO}_{2}, 300$ bar, $60^{\circ} \mathrm{C}$ & Antioxidant activity measurement: FRAP and TEAC & GC-MS & {$[100]$} \\
\hline Corn oil & Transesterification products & $\mathrm{CO}_{2}, 440$ bar, $100^{\circ} \mathrm{C}$ & Lipozyme treatment & HPLC-UV-ELSD $(205 \mathrm{~nm})$ & {$[101]$} \\
\hline Brewer's spent grain & Tocopherol & $\mathrm{CO}_{2}, 350$ bar, $40^{\circ} \mathrm{C}$ & Economic analysis & HPLC-UV (290 nm) & {$[18]$} \\
\hline Spent activated carbon & 2,2,3,3-tetrafluoro-1-propanol & $\mathrm{CO}_{2}, 89-190$ bar, $30-60{ }^{\circ} \mathrm{C}$ & Cold trap & GC-FID & {$[102]$} \\
\hline Lignin residues & Glycerol, guaiacol & Water, n.a. press., $400^{\circ} \mathrm{C}$ & -- & GC-MS, GC-FID & {$[103]$} \\
\hline Canola flakes & PUFA's & $\mathrm{CO}_{2}, 207$ bar, $35^{\circ} \mathrm{C}$ & Fungal fermentation & GC-MS & {$[104]$} \\
\hline Wood biomass & Bio-crude & Methanol, $20-100$ bar, $200-400{ }^{\circ} \mathrm{C}$ & SC-methanol & GC-TCD, GC-MS & [105] \\
\hline Aqueous waste streams & Organic solvents & $\mathrm{CO}_{2}, 100$ bar, $30-50^{\circ} \mathrm{C}$ & -- & GC-FID & {$[106]$} \\
\hline Silkworm pupae & Oil & $\mathrm{CO}_{2}, 200-300$ bar, $35-45^{\circ} \mathrm{C}$ & Chemometric optimization & GC-MS, GC-FID & {$[107]$} \\
\hline Pine (P. Pinaster) bark & Antioxidants & $\mathrm{CO}_{2}+$ Ethanol $100-300$ bar, $30-50^{\circ} \mathrm{C}$ & Comparison with Soxhlet & TLC, GC-MS, HPLC-UV (280 nm) & {$[108]$} \\
\hline
\end{tabular}


Journal of Chromatography A 1217(16): 2495-2511 (2010) http://dx.doi.org/10.1016/j.chroma.2009.12.019

Table 2.-. Summary of the works published on the extraction of bioactive and interesting compounds from plants by SFE in the period 2007-2009

\begin{tabular}{|c|c|c|c|c|c|}
\hline Plant material & $\begin{array}{c}\text { Compounds of } \\
\text { interest }\end{array}$ & $\begin{array}{l}\text { Related functional } \\
\text { activities }\end{array}$ & Extraction conditions & Analytical technique & Ref. \\
\hline $\begin{array}{l}\text { Cynanchum } \\
\text { paniculatum }\end{array}$ & Paeonol & $\begin{array}{l}\text { Anti-inflammatory, } \\
\text { antidiabetic, } \\
\text { cardiovascular } \\
\text { protective }\end{array}$ & $\begin{array}{c}\mathrm{CO}_{2}+\text { methanol, } 150 \mathrm{bar}, 55^{\circ} \mathrm{C}, 20 \mathrm{~min}(\text { static })+90 \mathrm{~min} \\
\text { (dynamic) }\end{array}$ & HSCCC, HPLC-DAD & {$[118]$} \\
\hline Ramulus cinnamoni & & $\begin{array}{l}\text { Antioxidant, } \\
\text { antimicrobial }\end{array}$ & $\mathrm{CO}_{2}, 230-410$ bar, $40-50^{\circ} \mathrm{C}$ & - & [119] \\
\hline Cassia tora $\mathrm{L}$. seeds & Volatile oil & Antioxidant & $\mathrm{CO}_{2}+$ ethyl acetate $(10 \%), 250 \mathrm{bar}, 45^{\circ} \mathrm{C}$ & GC-MS & {$[120]$} \\
\hline Cucscuta reflexa & Coumarin & $\begin{array}{l}\text { Anti-fungicidal, anti- } \\
\text { tumor }\end{array}$ & $\begin{array}{c}\mathrm{CO}_{2}, 248 \text { bar, } 55^{\circ} \mathrm{C} \text { (optimized through artificial neural } \\
\text { network model) }\end{array}$ & HPLC-UV $(280 \mathrm{~nm})$ & [121] \\
\hline $\begin{array}{l}\text { Cardamom (Elettaria } \\
\text { cardamoтит) }\end{array}$ & $\begin{array}{l}\text { Voltiles, fatty acids, } \\
\text { tocopherols }\end{array}$ & Antioxidant & $\mathrm{CO}_{2}, 300$ bar, $35^{\circ} \mathrm{C}$ & $\begin{array}{c}\text { GC-MS; HPLC-FD (ex: } 295 \\
\text { nm, em: } 330 \mathrm{~nm} \text { ); HPLC- } \\
\text { DAD }\end{array}$ & {$[122]$} \\
\hline $\begin{array}{l}\text { Black cumin (Nigella } \\
\text { sativa) }\end{array}$ & Essential oil & Antimicrobial & $\mathrm{CO}_{2}, 400$ bar, $40^{\circ} \mathrm{C}, 35 \mathrm{~min}$ & - & {$[123]$} \\
\hline Rhodiola rosea roots & Rosavin & $\begin{array}{c}\text { Antioxidant, anti-stress, } \\
\text { among others }\end{array}$ & $\mathrm{CO}_{2}+$ water $(10 \%), 200 \mathrm{bar}, 80^{\circ} \mathrm{C}, 3 \mathrm{~h}$ & HPLC-UV $(254 \mathrm{~nm})$ & {$[124]$} \\
\hline $\begin{array}{l}\text { Ginger (Zingiber } \\
\text { corallinum Hance) }\end{array}$ & Essential oil & Antipyretic & $\mathrm{CO}_{2}+$ methanol, $100 \mathrm{bar}, 30^{\circ} \mathrm{C}, 40 \mathrm{~min}$ & GC-MS & {$[125]$} \\
\hline $\begin{array}{c}\text { Anoectochilus } \\
\text { roxburghii }\end{array}$ & Phytosterols & $\begin{array}{l}\text { Anti-inflammatory, } \\
\text { anti-cancer }\end{array}$ & $\mathrm{CO}_{2}+$ ethanol, $250 \mathrm{bar}, 45^{\circ} \mathrm{C}, 1 \mathrm{~h}$ (static) $+1 \mathrm{~h}$ (dynamic) & HPLC-APCI-MS & {$[126]$} \\
\hline \multirow{2}{*}{$\begin{array}{l}\text { Valerian (Valiriana } \\
\text { officinalis L.) }\end{array}$} & Valerenic acid & Tranquilizing & $\mathrm{CO}_{2}+$ ethanol, $360 \mathrm{bar}, 37^{\circ} \mathrm{C}, 20 \mathrm{~min}$ & GC-MS & {$[127]$} \\
\hline & Sesquiterpenes & & $\mathrm{CO}_{2}, 150$ bar, $50^{\circ} \mathrm{C}$ & GC-FID; GC-MS & {$[131]$} \\
\hline Stevia rebaudiana & Glycosides & $\begin{array}{l}\text { Anti-inflammatory, } \\
\text { diuretic, among others }\end{array}$ & $\mathrm{CO}_{2}, 211 \mathrm{bar}, 80^{\circ} \mathrm{C}, 60 \mathrm{~min}$ & HPLC-UV $(210 \mathrm{~nm})$ & {$[128]$} \\
\hline $\begin{array}{c}\text { Braccharis } \\
\text { dracunculifolia }\end{array}$ & Phenolics & Antioxidant & $\mathrm{CO}_{2}, 400 \mathrm{bar}, 60^{\circ} \mathrm{C}, 20 \mathrm{~min}$ & HPLC-UV (280nm) & {$[130]$} \\
\hline Borago officinalis & Seed oil & & $\mathrm{CO}_{2}, 200$ bar, $50^{\circ} \mathrm{C}, 2.5 \mathrm{~h}$ (dynamic) & HPLC-DAD & {$[132]$} \\
\hline \multirow{2}{*}{$\begin{array}{c}\text { Coriander } \\
\text { (Coriandrum sativum } \\
\text { L) }\end{array}$} & Volatile oil & & $\mathrm{CO}_{2}, 90 \mathrm{bar}, 40^{\circ} \mathrm{C}, 100 \mathrm{~min}$ & GC-MS & [129] \\
\hline & Isocoumarins & & $\mathrm{CO}_{2}, 80$ bar, $35^{\circ} \mathrm{C}, 2 \mathrm{~h}$ (dynamic) & $\begin{array}{l}\text { High-speed counter-current } \\
\text { chromatography (HSCCC) }\end{array}$ & {$[133]$} \\
\hline $\begin{array}{l}\text { Chamomile } \\
\text { (Matricaria } \\
\text { chamomilla) }\end{array}$ & Essential oil & $\begin{array}{l}\text { Anti-inflammatory, } \\
\text { anti-spasmodic }\end{array}$ & $\mathrm{CO}_{2}, 250$ bar, $40^{\circ} \mathrm{C}, 90 \mathrm{~min}$ (dynamic) & HPLC-UV $(220 \mathrm{~nm})$ & {$[134]$} \\
\hline Vitex agnus castus & $\begin{array}{c}\text { Diterpenes, } \\
\text { triterpenes, casticin }\end{array}$ & & $\mathrm{CO}_{2}, 450$ bar, $45^{\circ} \mathrm{C}, 4 \mathrm{~h}$ (dynamic) & TLC; GC; HPLC & {$[135]$} \\
\hline $\begin{array}{l}\text { Lotus (Nelumbo } \\
\text { nucifera) }\end{array}$ & Germ oil & Antioxidant & $\mathrm{CO}_{2}, 320$ bar, $50{ }^{\circ} \mathrm{C}, 2 \mathrm{~h}$ (dynamic) & GC-MS & [137] \\
\hline Eugenia uniflora fruits & Carotenoids & Antioxidant & $\mathrm{CO}_{2}, 250$ bar, $60^{\circ} \mathrm{C}, 120 \mathrm{~min}$ (dynamic) & HPLC-DAD $(450 \mathrm{~nm})$ & {$[138]$} \\
\hline Garcinia mangostana & Xanthones & Antioxidant & $\mathrm{CO}_{2}+$ ethanol $(4 \%), 200 \mathrm{bar}, 40^{\circ} \mathrm{C}$ & HPLC-ESI-MS & {$[139]$} \\
\hline Sunflower & & Natural herbicide & $\mathrm{CO}_{2}, 500$ bar, $50^{\circ} \mathrm{C}, 15 \mathrm{~min}$ & - & {$[140]$} \\
\hline
\end{tabular}


Journal of Chromatography A 1217(16): 2495-2511 (2010) http://dx.doi.org/10.1016/j.chroma.2009.12.019

\begin{tabular}{|c|c|c|c|c|c|}
\hline $\begin{array}{l}\text { (Hellianthus annuus) } \\
\text { leaves }\end{array}$ & & & $\mathrm{CO}_{2}+$ water $(2 \%), 380 \mathrm{bar}, 50^{\circ} \mathrm{C}, 120 \mathrm{~min}$ & - & [141] \\
\hline \multirow{2}{*}{$\begin{array}{l}\text { Hyssop (Hyssopus } \\
\text { officinalis L) }\end{array}$} & Sabinene & $\begin{array}{l}\text { Anti-fungal, anti- } \\
\text { bacterial }\end{array}$ & $\begin{array}{c}\mathrm{CO}_{2}+\text { methanol }(1.5 \% \mathrm{v} / \mathrm{v}), 100 \text { bar, } 55^{\circ} \mathrm{C}, 30 \mathrm{~min} \\
(\text { dynamic) }\end{array}$ & GC-MS & [142] \\
\hline & Essential oil & & $\mathrm{CO}_{2}, 90$ bar, $40{ }^{\circ} \mathrm{C}$ (dynamic) & GC-MS & [136] \\
\hline Pinus sp. & Flavonoids & Antioxidant act. & $\mathrm{CO}_{2}+$ etanol $(3 \% \mathrm{v} / \mathrm{v}), 200 \mathrm{bar}, 40^{\circ} \mathrm{C}$ & HPLC-UV (280 nm) & [143] \\
\hline \multirow{2}{*}{ Rosehip (Rosa canina) } & Carotenoids & Antioxidant & $\mathrm{CO}_{2}, 450$ bar, $80^{\circ} \mathrm{C}, 150 \mathrm{~min}$ & HPLC-UV $(450 \mathrm{~nm})$ & [144] \\
\hline & Fatty acids & & $\mathrm{CO}_{2}, 450$ bar, $80^{\circ} \mathrm{C}, 3 \mathrm{~h}$ (dynamic) & GC-FID & [145] \\
\hline Hibiscus cannabinus & Oil & Antioxidant & $\mathrm{CO}_{2}, 200$ bar, $80^{\circ} \mathrm{C}, 150 \mathrm{~min}$ & - & [146] \\
\hline Salvia officinalis $\mathrm{L}$ & Essential oil & & $\mathrm{CO}_{2}, 128$ bar, $50^{\circ} \mathrm{C}, 3 \mathrm{~h}$ (dynamic) & GC-FID & [147] \\
\hline Satureja fruticosa & Volatiles & & $\mathrm{CO}_{2}, 90$ bar, $40^{\circ} \mathrm{C}-$ two separators & GC-FID; GC-MS & [148] \\
\hline $\begin{array}{l}\text { Eremanthus } \\
\text { erythropappus }\end{array}$ & $\alpha$-bisabolol & Anti-inflammatory & $\mathrm{CO}_{2}, 150$ bar, $40^{\circ} \mathrm{C}$ (dynamic) & - & [149] \\
\hline Vativeria zizanioides & Volatile oils & & $\mathrm{CO}_{2}+$ ethanol $(5 \%), 200$ bar, $40^{\circ} \mathrm{C}, 5 \mathrm{~h}$ & TLC; GC-FID & {$[150]$} \\
\hline Viscum album $L$ & Cytotoxic compouns & anticancer drugs & $\mathrm{CO}_{2}, 350 \mathrm{bar}, 35^{\circ} \mathrm{C}$ & GC-MS & [151] \\
\hline $\begin{array}{l}\text { Tabernaemontana } \\
\text { catharinensis }\end{array}$ & \multicolumn{2}{|c|}{ Antilehimaniosis drugs } & $\mathrm{CO}_{2}+$ Ethanol, 250 bar, $45^{\circ} \mathrm{C}$ & $\begin{array}{c}\text { TLC,GC-MS, IR, UV and } \\
\text { H1-NMR }\end{array}$ & {$[152]$} \\
\hline $\begin{array}{l}\text { Salvia officinalis } \\
\text { ethanolic tinctures }\end{array}$ & Antiviral compounds & Anti tomatitis virus & $\mathrm{CO}_{2}, 200-500$ bar, $60-100{ }^{\circ} \mathrm{C}$ & HPLC, GC & [153] \\
\hline $\begin{array}{l}\text { Hippophae } \\
\text { rhamnoides }\end{array}$ & $\begin{array}{l}\text { Coagulation related } \\
\text { compounds }\end{array}$ & $\begin{array}{c}\text { Antithrombotic and } \\
\text { antiaterogenic }\end{array}$ & $\mathrm{CO}_{2}, 450$ bar, $60^{\circ} \mathrm{C}$ & GC-FID, HPLC-DAD & {$[154,155]$} \\
\hline Bamboo shavings & Triterpenoids & antifatigue & $\mathrm{CO}_{2}+$ Co-solvents, $250-350$ bar, $50-65^{\circ} \mathrm{C}$ & Biochemical kits & [156] \\
\hline
\end{tabular}


Journal of Chromatography A 1217(16): 2495-2511 (2010) http://dx.doi.org/10.1016/j.chroma.2009.12.019

Table 3.- Summary of the works published on the extraction of bioactive and interesting compounds from algae and microalgae by SFE.

\begin{tabular}{|c|c|c|c|c|c|}
\hline Specie & $\begin{array}{c}\text { Compounds of } \\
\text { interest }\end{array}$ & $\begin{array}{c}\text { Related functional } \\
\text { activities }\end{array}$ & Extraction conditions & Analytical technique & Ref. \\
\hline \multirow{3}{*}{ Dunaliella salina } & $\beta$-carotene isomers & Antioxidant & $\mathrm{CO}_{2}, 437 \mathrm{bar}, 40^{\circ} \mathrm{C}, 10 \mathrm{~min}$ (static) $+90 \mathrm{~min}$ (dynamic) & HPLC-DAD (450 nm) & [159] \\
\hline & $\begin{array}{c}\text { Carotenoids, } \\
\text { chlorophyll }\end{array}$ & Antioxidant & $\mathrm{CO}_{2}, 400 \mathrm{bar}, 60^{\circ} \mathrm{C}, 180 \mathrm{~min}$ (dynamic) & $\begin{array}{c}\text { UV spectrometry }(665,480 \\
\mathrm{nm})\end{array}$ & {$[160]$} \\
\hline & $\begin{array}{l}\text { Carotenoids, } \\
\text { chlorophyll }\end{array}$ & Antioxidant & $\mathrm{CO}_{2}+$ ethanol (5\%), $400 \mathrm{bar}, 60^{\circ} \mathrm{C}, 3 \mathrm{~h}$ (dynamic) & $\begin{array}{c}\text { UV spectrometry }(665,480 \\
\mathrm{nm})\end{array}$ & {$[161]$} \\
\hline $\begin{array}{c}\text { Nanochloropsis } \\
\text { gaditana }\end{array}$ & $\begin{array}{l}\text { Carotenoids, } \\
\text { chlorophyll }\end{array}$ & Antioxidant & $\mathrm{CO}_{2}+$ ethanol (5\%), $500 \mathrm{bar}, 60^{\circ} \mathrm{C}, 3 \mathrm{~h}$ (dynamic) & $\begin{array}{c}\text { UV spectrometry }(665,480 \\
n m)\end{array}$ & {$[161]$} \\
\hline \multirow{2}{*}{ Synechococcus sp. } & $\begin{array}{c}\text { Carotenoids, } \\
\text { chlorophyll }\end{array}$ & Antioxidant & $\mathrm{CO}_{2}, 300 \mathrm{bar}, 50^{\circ} \mathrm{C}, 3 \mathrm{~h}$ (dynamic) & $\begin{array}{c}\text { UV spectrometry }(665,480 \\
n m)\end{array}$ & [161] \\
\hline & $\begin{array}{c}\text { Carotenoids, } \\
\text { chlorophyll }\end{array}$ & Antioxidant & $\begin{array}{c}\mathrm{CO}_{2}, 300 \text { bar, } 50^{\circ} \mathrm{C}, 3 \mathrm{~h} \text { (dynamic) - carotenoids } \\
\mathrm{CO}_{2}, 500 \mathrm{bar}, 60^{\circ} \mathrm{C}, 3 \mathrm{~h} \text { (dynamic) - chlorophyll a }\end{array}$ & - & {$[162]$} \\
\hline $\begin{array}{c}\text { Dictyoperis } \\
\text { membranacea }\end{array}$ & Volatiles & Antimicrobial & $\mathrm{CO}_{2}, 91 \mathrm{bar}, 40^{\circ} \mathrm{C}, 30 \mathrm{~min}$ (dynamic) & GC-MS & {$[163]$} \\
\hline \multirow{2}{*}{ Chlorella pyrenoidosa } & Lutein & $\begin{array}{c}\text { Prevention macular } \\
\text { degenration }\end{array}$ & $\mathrm{CO}_{2}+$ ethanol, 400 bar, $32^{\circ} \mathrm{C}, 3 \mathrm{~h}$ (dynamic) & - & {$[164]$} \\
\hline & Lutein & Antioxidant & $\mathrm{CO}_{2}+$ ethanol $(50 \%), 250$ bar, $50^{\circ} \mathrm{C}, 4 \mathrm{~h}$ (dynamic) & HPLC-DAD & [165] \\
\hline Chlorella vulgaris & $\begin{array}{c}\text { Carotenoids, fatty } \\
\text { acids }\end{array}$ & Antioxidant & $\mathrm{CO}_{2}+$ ethanol, $300 \mathrm{bar}, 40^{\circ} \mathrm{C}$ & GC-FID; HPLC & {$[166]$} \\
\hline \multirow{2}{*}{ Spirulina platensis } & Vitamin E & Antioxidant & $\mathrm{CO}_{2}, 220$ bar, $83.3^{\circ} \mathrm{C}$ (dynamic) & $\begin{array}{c}\text { HPLC-FD (ex. } 295 \mathrm{~nm}, \text { em. } \\
350 \mathrm{~nm})\end{array}$ & {$[167,168]$} \\
\hline & $\gamma$-linolenic acid & Antimicrobial & $\mathrm{CO}_{2}+$ ethanol, $400 \mathrm{bar}, 40^{\circ} \mathrm{C}, 1 \mathrm{~h}$ (dynamic) & GC-FID & {$[169,170]$} \\
\hline
\end{tabular}


Table 4.-. Summary of the works published on the extraction of toxic compounds by SFE in the period 2007-2009

\begin{tabular}{|c|c|c|c|c|c|}
\hline Compound & Matrix & Extraction conditions & Other features & Analytical technique & Ref. \\
\hline Dioxins and PCB & Sediments and soils & $\mathrm{CO}_{2}+\mathrm{H}_{2} \mathrm{O}, 300$ bar, $130^{\circ} \mathrm{C}$ & Compared with soxhlet & GC-MS & {$[221]$} \\
\hline Polycyclic and nitro musks & municipal wastewater & $\mathrm{CO}_{2}, 358$ bar, $80^{\circ} \mathrm{C}$ & Silica sorbent trapping & GC-MS & {$[222]$} \\
\hline 15 organohalogenated pollutants & $\begin{array}{l}\text { Turbot, clam, mussel and cockle } \\
\text { from aquaculture }\end{array}$ & $\mathrm{CO}_{2}, 210 \mathrm{bar}, 60^{\circ} \mathrm{C}$ & \begin{tabular}{c|} 
Clean-up involved different \\
adsorbents, complete factorial design
\end{tabular} & GC-MS/MS & [223] \\
\hline Fluoroquinolones & Pig tissues & $\mathrm{CO}_{2}+$ Methanol, $300 \mathrm{bar}, 80^{\circ} \mathrm{C}$ & $\mathrm{Na}_{4}$ EDTA inner matrix & HPLC & [224] \\
\hline $\begin{array}{l}\text { Organochlorine pesticide and heavy- } \\
\text { metal }\end{array}$ & Epimedium brevicornum Maxim & $\mathrm{CO}_{2}, 150 \mathrm{bar}, 60^{\circ} \mathrm{C}$ & Compared with soxhlet & GC, HPLC, AAS & {$[225]$} \\
\hline Radiolitic hydrocarbons & Irradiated cheese & $\mathrm{CO}_{2}, 150$ bar, $80{ }^{\circ} \mathrm{C}$ & Tenax trap & GC-MS & [226] \\
\hline PAH & $\begin{array}{l}\text { earthworms in manufactured-gas } \\
\text { plant site soils }\end{array}$ & $\mathrm{CO}_{2}, 200 \mathrm{bar}, 50^{\circ} \mathrm{C}$ & Compared with soxhlet & Headspace GC-MS & [227] \\
\hline Insecticides & Melon & $\mathrm{CO}_{2}, 300$ bar, $50{ }^{\circ} \mathrm{C}$ & $\begin{array}{l}\text { Hydromatrix and anhydrous } \\
\text { magnesium sulfate sorbents }\end{array}$ & GC-MS & [228] \\
\hline PAH & Lepidium sativum & $\begin{array}{c}\mathrm{CO}_{2}+\text { Methanol, } \\
{ }^{\circ} \mathrm{C}-200 \text { bar, } 40-120\end{array}$ & - & $\begin{array}{c}\text { HPLC- }^{3 \mathrm{D}} \text { FLD (Ex. } 260 \mathrm{~nm}, \text { Em. } \\
350,420,440 \text {, and } 500 \mathrm{~nm})\end{array}$ & [229] \\
\hline $\mathrm{PAH}$ & Aged industrial soils & $\mathrm{CO}_{2}, 300 \mathrm{bar}, 50^{\circ} \mathrm{C}$ & $\begin{array}{l}\text { Study of efficacy of myco- } \\
\text { remediation }\end{array}$ & HPLC-DAD (282 nm) & [230] \\
\hline $\mathrm{PCB}$ & Sediments & $\mathrm{CO}_{2}, 120-365$ bar, $40-100^{\circ} \mathrm{C}$ & Extraction completed with PLE & TOC, GC & {$[231]$} \\
\hline 15 pesticides & River sediments & $\mathrm{CO}_{2}, 350-400$ bar, $60-100^{\circ} \mathrm{C}$ & $\begin{array}{l}\mathrm{H}_{2} \mathrm{O} \text { and acetone as modifiers, } \\
\text { toluene collection }\end{array}$ & GC & [232] \\
\hline PAH & River floodplain soils & $\mathrm{CO}_{2}, 200$ bar, $50^{\circ} \mathrm{C}$ & C18 trapping & GC-MS & {$[233]$} \\
\hline Artemisin & Soils & $\mathrm{CO}_{2}+$ Ethanol, 300 bar, $50^{\circ} \mathrm{C}$ & -- & HPLC & [234] \\
\hline PAH & Seaweed before and after oil spill & $\mathrm{CO}_{2}, 256$ bar, $100^{\circ} \mathrm{C}$ & C18 trapping & $\begin{array}{c}\text { HPLC-FLD (Ex. 250-296nm, Em. } \\
302-456 \mathrm{~nm})\end{array}$ & [235] \\
\hline Orbifloxacin & Milk and plasma & $\begin{array}{c}\mathrm{CO}_{2}+\text { Methanol, 250-320 bar, 60-150 } \\
{ }^{\circ} \mathrm{C}\end{array}$ & -- & $\begin{array}{c}\text { HPLC-FLD (Ex. } 278 \text { nm, Em. } 450 \\
n m)\end{array}$ & [236] \\
\hline Dioxins and PCB & Fish oil & $\mathrm{CO}_{2}, 300$ bar, $70{ }^{\circ} \mathrm{C}$ & $\begin{array}{l}\text { Countercurrent extraction, coupled } \\
\text { to activated carbon }\end{array}$ & GC-MS and GC-FID & [237] \\
\hline
\end{tabular}


Journal of Chromatography A 1217(16): 2495-2511 (2010) http://dx.doi.org/10.1016/j.chroma.2009.12.019

Table 5.-. Summary of the works published on the metal recovery by SFE in the period 2007-2009

\begin{tabular}{|c|c|c|c|c|}
\hline Metal & Matrix & Extraction conditions & Chelating agent & Ref. \\
\hline $\mathrm{Pd}, \mathrm{Pt}, \mathrm{Rh}$ & Spent automobile catalytic converters & $\mathrm{CO}_{2}, 300$ bar, $40-80^{\circ} \mathrm{C}$ & Terc-butylphenoxo (TBP) ligands & {$[238]$} \\
\hline $\mathrm{Cr}, \mathrm{Cu}, \mathrm{As}$ & Treated wood & $\mathrm{CO}_{2}, 200 \mathrm{bar}, 60^{\circ} \mathrm{C}$ & organophosphorus Cyanex 302 & [239] \\
\hline Th & Tissue paper residues & $\mathrm{CO}_{2}, 200 \mathrm{bar}, 60^{\circ} \mathrm{C}$ & organophosphorus reagents (TBP, TOPO, TPP, TPPO, TBPO) & [240] \\
\hline $\mathrm{Ur}$ & Radioactive metal wastes & $\mathrm{CO}_{2}, 200 \mathrm{bar}, 40^{\circ} \mathrm{C}$ & surfactant (NP-4) & [241] \\
\hline $\mathrm{Cu}$ & Copper(0) foil & $\mathrm{CO}_{2}, 240 \mathrm{bar}, 60^{\circ} \mathrm{C}$ & dialkyldithiocarbamate lithium salts & [242] \\
\hline In(III) & Acidic aqueous solution & $\mathrm{CO}_{2}, 138$ bar, $70^{\circ} \mathrm{C}$ & $\begin{array}{l}\beta \text {-diketone (AcAcH), fluorinated } \beta \text {-diketone (TTAH), thiopyridine } \\
\text { (PySH), and piperidinyldithiocarbamic acid }\end{array}$ & [243] \\
\hline $\mathrm{Ga}(\mathrm{III})$ & Acidic aqueous solution & $\mathrm{CO}_{2}, 205$ bar, $70^{\circ} \mathrm{C}$ & AcAcH, TTAH and PySH & [244] \\
\hline $\mathrm{Nd}(\mathrm{III}), \mathrm{Eu}(\mathrm{III})$ & Acidic aqueous solution & $\mathrm{CO}_{2}, 200$ bar, $50^{\circ} \mathrm{C}$ & Oxa-diamides (TBODA) & [245] \\
\hline
\end{tabular}

